Article

\title{
Effect of A-Site Cation Ordering on Chemical Stability, Oxygen Stoichiometry and Electrical Conductivity in Layered $\mathrm{LaBaCo}_{2} \mathrm{O}_{5+\delta}$ Double Perovskite
}

\author{
Carlos Bernuy-Lopez *, Kristin Høydalsvik, Mari-Ann Einarsrud and Tor Grande \\ Department of Material Science and Engineering, NTNU Norwegian University of Science and Technology, \\ Trondheim NO-7491, Norway; kristin.hoydalsvik@ntnu.no (K.H.); mari-ann.einarsrud@ntnu.no (M.-A.E.); \\ tor.grande@ntnu.no (T.G.) \\ * Correspondence: carlos.bernuy-lopez@ntnu.no; Tel.: +47-73-59-40-59 \\ Academic Editor: Lioz Etgar \\ Received: 22 January 2016; Accepted: 23 February 2016; Published: 3 March 2016
}

\begin{abstract}
The effect of the A-site cation ordering on the chemical stability, oxygen stoichiometry and electrical conductivity in layered $\mathrm{LaBaCO}_{2} \mathrm{O}_{5+\delta}$ double perovskite was studied as a function of temperature and partial pressure of oxygen. Tetragonal A-site cation ordered layered $\mathrm{LaBaCo}_{2} \mathrm{O}_{5}+\delta$ double perovskite was obtained by annealing cubic A-site cation disordered $\mathrm{La}_{0.5} \mathrm{Ba}_{0.5} \mathrm{CoO}_{3} \delta$ perovskite at $1100{ }^{\circ} \mathrm{C}$ in $\mathrm{N}_{2}$. High temperature $\mathrm{X}$-ray diffraction between room temperature (RT) and $800{ }^{\circ} \mathrm{C}$ revealed that $\mathrm{LaBaCO}_{2} \mathrm{O}_{5+\delta}$ remains tetragonal during heating in oxidizing atmosphere, but goes through two phase transitions in $\mathrm{N}_{2}$ and between $450{ }^{\circ} \mathrm{C}$ and $675^{\circ} \mathrm{C}$ from tetragonal $\mathrm{P} 4 / \mathrm{mmm}$ to orthorhombic Pmmm and back to $\mathrm{P} 4 / \mathrm{mmm}$ due to oxygen vacancy ordering followed by disordering of the oxygen vacancies. An anisotropic chemical and thermal expansion of $\mathrm{LaBaCo}_{2} \mathrm{O}_{5+\delta}$ was demonstrated. $\mathrm{La}_{0.5} \mathrm{Ba}_{0.5} \mathrm{CoO}_{3-\delta}$ remained cubic at the studied temperature irrespective of partial pressure of oxygen. $\mathrm{LaBaCo}_{2} \mathrm{O}_{5+\delta}$ is metastable with respect to $\mathrm{La}_{0.5} \mathrm{Ba}_{0.5} \mathrm{CoO}_{3-\delta}$ at oxidizing conditions inferred from the thermal evolution of the oxygen deficiency and oxidation state of $\mathrm{Co}$ in the two materials. The oxidation state of $\mathrm{Co}$ is higher in $\mathrm{La}_{0.5} \mathrm{Ba}_{0.5} \mathrm{CoO}_{3} \delta$ resulting in a higher electrical conductivity relative to $\mathrm{LaBaCO}_{2} \mathrm{O}_{5+\delta}$. The conductivity in both materials was reduced with decreasing partial pressure of oxygen pointing to a p-type semiconducting behavior.
\end{abstract}

Keywords: layered double perovskite (LDP); cation and anion ordering; chemical expansion; solid oxide fuel cells

\section{Introduction}

Layered double perovskite (LDP) materials with mixed ionic-electronic conductivity and high catalytic activity have been heavily investigated because of their potential application in electrochemical devices such as solid oxide fuel cells (SOFC) [1-8] or gas separation membranes $[9,10]$. These materials are described with a general formula $L n B a M_{2} \mathrm{O}_{5+\delta}$ where $L n$ is a lanthanide metal or $\mathrm{Y}$ and $M$ is a transition metal. In this double perovskite $\mathrm{AA}^{\prime} \mathrm{B}_{2} \mathrm{O}_{6}$-type crystal structure, $L n$ and $\mathrm{Ba}$ are occupying the A-site in the perovskite structure while $M$ occupies the B-site. A-site cation ordering is adopted due to the large difference in size of $\mathrm{Ba}$ and $L n$ with $L n \mathrm{O}$ and $\mathrm{BaO}$ layers in dodecahedral coordination separated by $\mathrm{MO}_{6}$ layers in octahedral coordination [11]. The cation ordering leads to a tetragonal symmetry $P 4 / m m m\left(a_{p} \times a_{p} \times 2 a_{p}\right)$ in comparison with the cation disordered $\mathrm{Ln}_{0.5} \mathrm{Ba}_{0.5} \mathrm{MO}_{3-\delta}$ counterpart which adopts a cubic symmetry [12,13]. A-site cation ordering has been shown to be beneficial for the performance of the material as a SOFC cathode. For example, A-site cation ordered $\mathrm{GdBaMnFeO}_{5+\delta}$ has been reported to possess superior cathode SOFC properties compared with the cubic perovskite $\mathrm{Gd}_{0.5} \mathrm{Ba}_{0.5} \mathrm{Mn}_{0.5} \mathrm{Fe}_{0.5} \mathrm{O}_{3-\delta}$ counterpart [14]. 
In addition to cation ordering, oxygen deficiency at elevated temperatures may also lead to ordering of oxygen vacancies, e.g., for $\mathrm{LaBaCo}_{2} \mathrm{O}_{5+\delta}$ [15], $\mathrm{PrBaCo}_{2} \mathrm{O}_{5+\delta}$ [16] or $\mathrm{GdBaCo}_{2} \mathrm{O}_{5+\delta}$ an orthorhombic structure with space group Pmmm $\left(a_{p} \times 2 a_{p} \times 2 a_{p}\right)$ is adopted when the oxygen vacancies reaches a certain level dependent on the type of lanthanide and transition metals [13]. The oxygen vacancies are located in the $\mathrm{LnO}$ layer of the double perovskite structure in order to compensate for the size difference between $L n$ and Ba [5,15,17-19]. In contrast to A-site cation ordering, the oxygen vacancy ordering is not beneficial for oxide-ion conduction [20,21]. A specific notation is introduced to highlight the presence of oxygen vacancies. Chemical formula is commonly written as $\mathrm{LaBaCo}_{2} \mathrm{O}_{5+\delta}$ instead of $\mathrm{LaBaCO}_{2} \mathrm{O}_{6-\delta}$ in order to emphasize this high oxygen content deficiency and it does not have to be mixed with the brownmillerite notation [22].

Several authors have reported on the thermal expansion of cation disordered $\mathrm{La}_{0.5} \mathrm{Ba}_{0.5} \mathrm{CoO}_{3-\delta}$ material $[7,23]$, but no data are available for A-site cation ordered $\mathrm{LaBaCo}_{2} \mathrm{O}_{5+\delta}$. Chemical expansion of these materials have not been reported to the best of our knowledge. High thermal and chemical expansions are critical for the thermo-mechanical stability of electrochemical devices such as SOFC and gas separation membranes [24-27]. Significant mismatch in thermal expansion between membranes and sealing materials or an electrode and an electrolyte in a SOFC will induce stresses during thermal cycling. Moreover, chemical expansion gives additional stresses when the material is exposed to a gradient in the chemical potential of oxygen, which is detrimental for the mechanical stability of high temperature electrochemical devices [28].

Here, we report a systematic study of the thermal evolution of the crystal structure, oxygen non-stoichiometry and electrical properties of $\mathrm{LaBaCo}_{2} \mathrm{O}_{5+\delta}$ and $\mathrm{La}_{0.5} \mathrm{Ba}_{0.5} \mathrm{CoO}_{3-\delta}$. Particular attention is given to the effect of both cation and oxygen vacancy ordering. The data are discussed in detail in order to correlate the changes of the crystal structure observed by high temperature $\mathrm{X}$-ray diffraction and electrical conductivity with the oxygen deficiency observed by thermogravimetrical analysis.

\section{Results}

Ex-situ X-ray diffraction (XRD) patterns of $\mathrm{La}_{0.5} \mathrm{Ba}_{0.5} \mathrm{CoO}_{3-\delta}$ and $\mathrm{LaBaCo}_{2} \mathrm{O}_{5+\delta}$ after annealing in pure $\mathrm{O}_{2}$ are shown in Figure 1. The $\mathrm{La}_{0.5} \mathrm{Ba}_{0.5} \mathrm{CoO}_{3-\delta}$ perovskite synthesized by calcination of the precursor powder obtained by spray pyrolysis and thermally annealed at $1100{ }^{\circ} \mathrm{C}$ for $12 \mathrm{~h}$ in air was single phase material (Figure 1a) that could be indexed to a simple cubic perovskite with space group $\operatorname{Pm} \overline{3} m$. The oxygen stoichiometry of the material after annealing at $350{ }^{\circ} \mathrm{C}$ in oxygen was $\mathrm{La}_{0.5} \mathrm{Ba}_{0.5} \mathrm{CoO}_{2.98 \pm 0.01}$, determined by thermogravimetry reduction in $5 \% \mathrm{H}_{2}$ in $\mathrm{N}_{2}$ to its metallic and oxide components, which was confirmed by XRD data. In order to obtain the A-site cation ordered layered double perovskite $\mathrm{LaBaCo}_{2} \mathrm{O}_{5+\delta}$, the precursor powder was calcined at $1100{ }^{\circ} \mathrm{C}$ for $12 \mathrm{~h}$ in $\mathrm{N}_{2}$. This calcination step led to a material with high oxygen deficiency and poor crystallinity (Figure 1c). Annealing of this material in pure $\mathrm{O}_{2}$ at $350{ }^{\circ} \mathrm{C}$ for $24 \mathrm{~h}$ resulted in a single phase material with significantly improved crystallinity (Figure 1d), and the diffraction pattern could be indexed in a tetragonal symmetry with space group $P 4 / \mathrm{mmm}$. The absolute oxygen content of this double perovskite annealed in $\mathrm{O}_{2}$ was determined by thermal gravimetrical analysis to $\mathrm{LaBaCo}_{2} \mathrm{O}_{6.00 \pm 0.01}$. The full reduction of the material was confirmed by XRD data.

Rietveld refinements of the X-ray diffraction data at room temperature confirmed, the cubic structure of the A-site cation disordered $\mathrm{La}_{0.5} \mathrm{Ba}_{0.5} \mathrm{CoO}_{2.98}$, and a tetragonal structure of the layered double perovskite $\mathrm{LaBaCo}_{2} \mathrm{O}_{6.00}$ showing A-site cation ordering. These findings are in good agreement with the previous works by Rautama et al. [29]. Further details about the Rietveld refinement analysis are given below.

Figure 2 shows the high temperature $X$-ray diffraction data collected for both $\mathrm{La}_{0.5} \mathrm{Ba}_{0.5} \mathrm{CoO}_{3-\delta}$ and $\mathrm{LaBaCo}_{2} \mathrm{O}_{5+\delta}$ in $\mathrm{O}_{2}$. In the case of $\mathrm{La}_{0.5} \mathrm{Ba}_{0.5} \mathrm{CoO}_{3-\delta}$, the structure remains cubic in the whole temperature range, and both A-site cations and oxygen vacancies formed upon heating remain disordered (Figure 2a). In the case of the layered perovskite, the material remains tetragonal and cation 
ordered in the whole temperature range while oxygen vacancies formed upon heating were disordered (Figure $2 b$ ). The Bragg reflections (Figure 2) are shifted to lower $2 \theta$ with increasing temperature due to thermal expansion, but the shift becomes more pronounced at high temperature due to both thermal and chemical expansion. This expansion was observed in all the atmospheres.

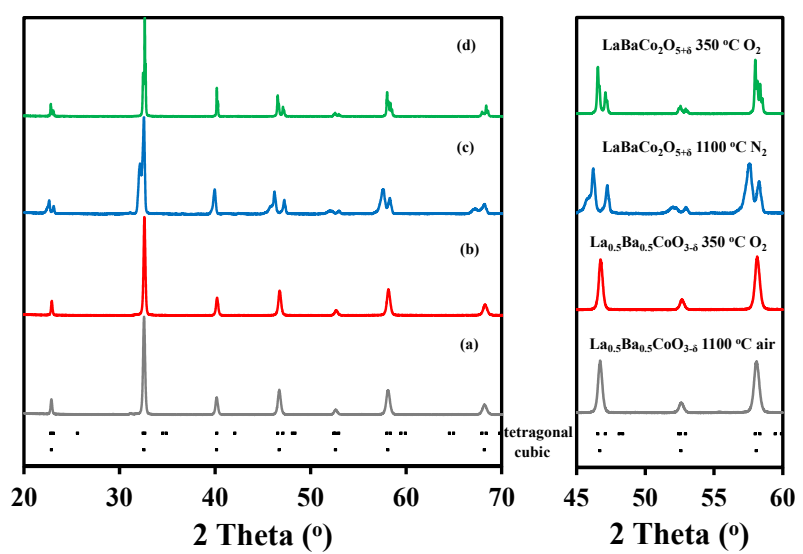

Figure 1. Full range and selected range $\mathrm{X}$-ray diffraction patterns recorded at room temperature of: (a) $\mathrm{La}_{0.5} \mathrm{Ba}_{0.5} \mathrm{CoO}_{3-\delta}$ after treatment at $1100{ }^{\circ} \mathrm{C}$ for $12 \mathrm{~h}$ in air; (b) $\mathrm{La}_{0.5} \mathrm{Ba}_{0.5} \mathrm{CoO}_{3-\delta}$ after treatment at $350{ }^{\circ} \mathrm{C}$ for $24 \mathrm{~h}$ in $\mathrm{O}_{2} ;$ (c) $\mathrm{LaBaCo}_{2} \mathrm{O}_{5+\delta}$ after treatment at $1100{ }^{\circ} \mathrm{C}$ for $12 \mathrm{~h}$ in $\mathrm{N}_{2}$; and (d) $\mathrm{LaBaCo}_{2} \mathrm{O}_{5+\delta}$ after treatment at $350{ }^{\circ} \mathrm{C}$ for $24 \mathrm{~h}$ in $\mathrm{O}_{2}$. The Bragg reflections for both tetragonal and cubic cells are included at the bottom.
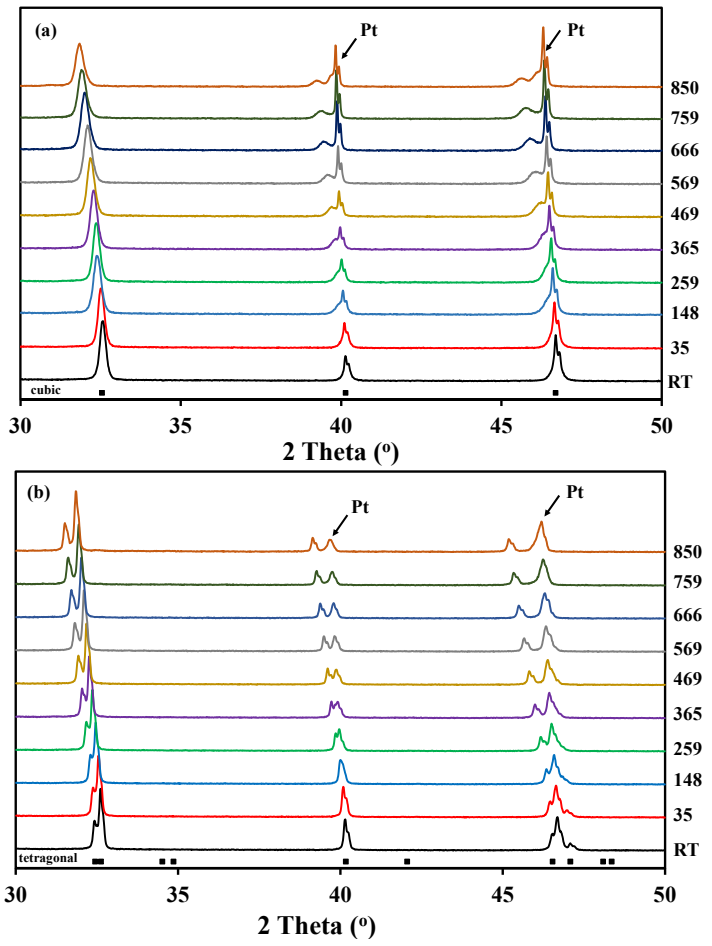

Figure 2. High temperature $\mathrm{X}$-ray diffraction patterns measured in pure $\mathrm{O}_{2}$ from room temperature to $850{ }^{\circ} \mathrm{C}$ for:(a) A-site cation disordered $\mathrm{La}_{0.5} \mathrm{Ba}_{0.5} \mathrm{CoO}_{3-\delta}$; and (b) A-site cation order and oxygen vacancy disordered $\mathrm{LaBaCO}_{2} \mathrm{O}_{5+\delta}$. The Bragg reflections for both cubic and tetragonal cells are included at the bottom. 
The high temperature X-ray diffraction data collected for $\mathrm{LaBaCo}_{2} \mathrm{O}_{5+\delta}$ in $\mathrm{N}_{2}$ are shown in Figure 3. A shift of the Bragg reflection to lower $2 \theta$ was also observed due to both thermal and chemical expansion, but in addition two phase transitions were observed during heating in $\mathrm{N}_{2}$. A change to a lower symmetry was observed between $450{ }^{\circ} \mathrm{C}$ and $675^{\circ} \mathrm{C}$ due to the splitting of the (010), (012) and (020) reflections, as marked with an arrow for (010) and (020) in Figure 3. In this range of temperatures, the XRD patterns can be indexed to an $a_{p} \times 2 a_{p} \times 2 a_{p}$ orthorhombic space group Pmmm previously shown by Rautama et al. [15] for $\mathrm{LaBaCo}_{2} \mathrm{O}_{5.5}$, which takes into account the ordering of the oxygen vacancies in addition to A-site cation ordering.
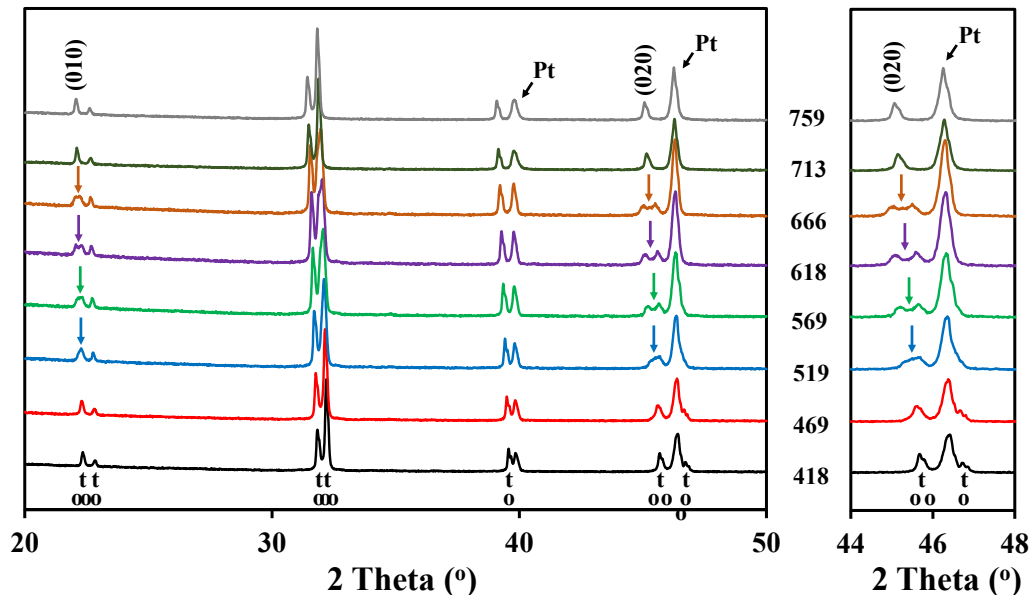

Figure 3. High temperature $\mathrm{X}$-ray diffraction patterns for the layered double perovskite $\mathrm{LaBaCo}_{2} \mathrm{O}_{5+\delta}$ in $\mathrm{N}_{2}$ from $418{ }^{\circ} \mathrm{C}$ to $759{ }^{\circ} \mathrm{C}$. The inset shows the range of temperatures where the splitting of (020) is observed. At the bottom of the figure, the Bragg reflections for both tetragonal and orthorhombic structures of $\mathrm{LaBaCO}_{2} \mathrm{O}_{5+\delta}$ are shown.

Typical Rietveld refinements of the X-ray diffraction patterns of $\mathrm{La}_{0.5} \mathrm{Ba}_{0.5} \mathrm{CoO}_{3-\delta}$ and $\mathrm{LaBaCo}_{2} \mathrm{O}_{6-\delta}$ materials at $600{ }^{\circ} \mathrm{C}$ in $\mathrm{O}_{2}$ and $\mathrm{N}_{2}$ are shown in Figure 4. The Rietveld refinement analysis confirms the cubic (Figure 4a), tetragonal (Figure 4b) and orthorhombic (Figure 4c) crystal structures at both room and high temperature, as suggested above. The crystallographic data determined by the refinements are summarized in Table 1.

The unit cell volume as well as the mass change as a function of temperature for both the A-site disordered (Figure $5 a$ ) and ordered (Figure $5 b$ ) materials in $\mathrm{O}_{2}$, air and $\mathrm{N}_{2}$ are shown in Figure 5. In the case of the A-site disordered material in $\mathrm{O}_{2}$, a small mass gain is observed at low temperatures due to oxidation reflecting a small initial oxygen deficiency. This oxidation is not observed in the case of $\mathrm{LaBaCo}_{2} \mathrm{O}_{5+\delta}$ because the material was fully oxidized. It is also important to notice that the A-site ordered material demonstrates a larger mass loss than the A-site disordered counterpart. The onset of the thermal reduction is observed as low as $\sim 250^{\circ} \mathrm{C}$, which reflects the high mobility of oxygen anions in both materials and creation of oxygen vacancies. Finally, the onset of the thermal reduction is at a slightly lower temperature for the A-site ordered material than for the A-site disordered one.

The temperature dependence of the unit cell parameters for the A-site ordered material in the three different atmospheres is included in Figure 6. For all atmospheres, the unit cell parameter $a$ expands more rapidly relative to the $c$ parameter, which demonstrates the strong anisotropic chemical expansion of the material. In addition, the cell parameters a and c show different behavior in the different atmospheres. The $a$ parameter is smaller for higher $\mathrm{pO}_{2}$, independently on the temperature. However, the $c$ parameter is smaller at lower temperatures and $\mathrm{pO}_{2}$, while at higher temperatures the opposite behavior is apparent. 

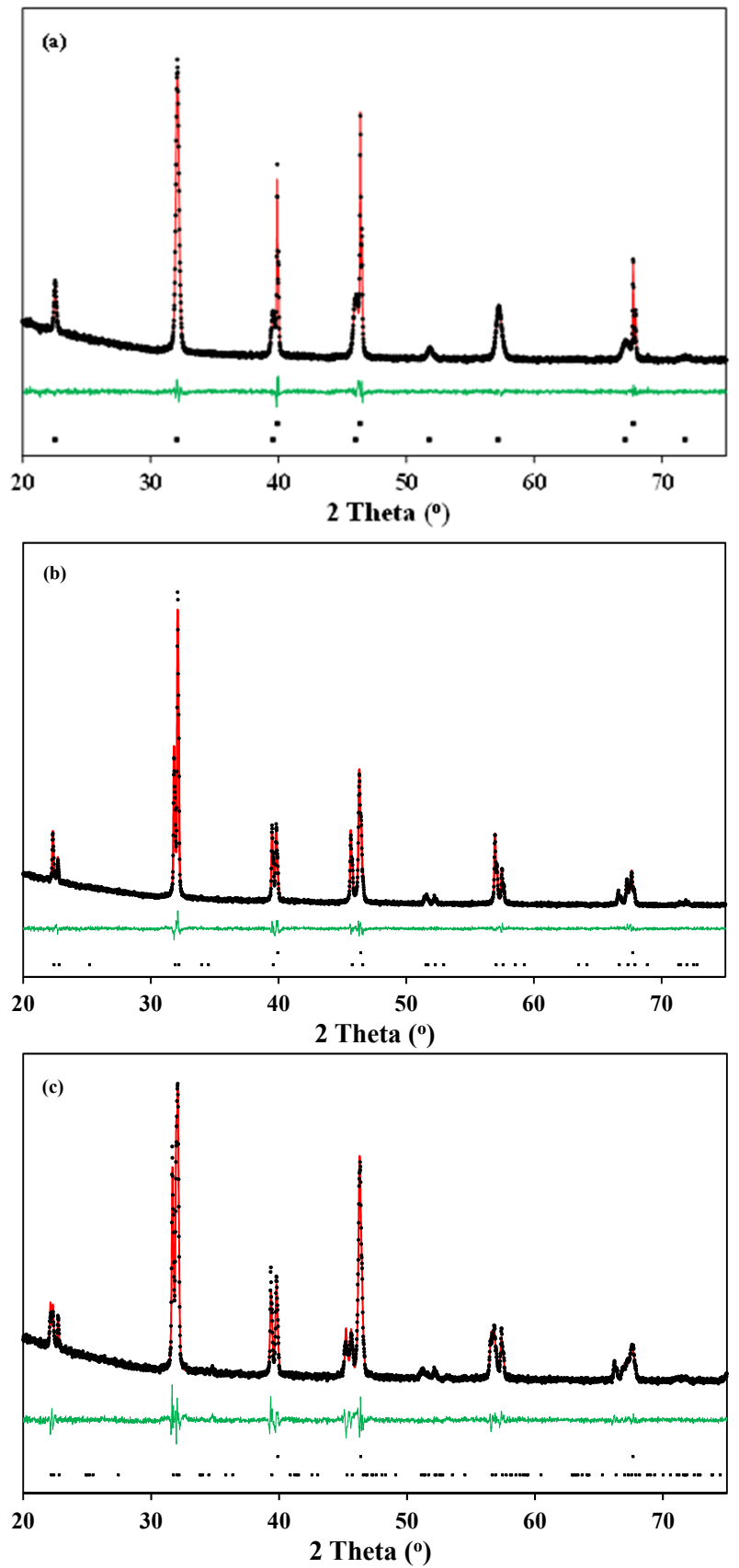

Figure 4. Typical Rietveld fit of the X-ray diffraction patterns of: (a) cubic $(P m \overline{3} m) \mathrm{La}_{0.5} \mathrm{Ba}_{0.5} \mathrm{CoO}_{3-\delta}$ at $600{ }^{\circ} \mathrm{C}$ in $\mathrm{O}_{2} ;\left(\right.$ b) tetragonal $(P 4 / \mathrm{mmm}) \mathrm{LaBaCo}_{2} \mathrm{O}_{5+\delta}$ at $600{ }^{\circ} \mathrm{C}$ in $\mathrm{O}_{2}$; and (c) orthorhombic $(P m m m) \mathrm{LaBaCO}_{2} \mathrm{O}_{5+\delta}$ at $600{ }^{\circ} \mathrm{C}$ in $\mathrm{N}_{2}$. The Bragg reflections of $\mathrm{Pt}$ and either $\mathrm{La}_{0.5} \mathrm{Ba}_{0.5} \mathrm{CoO}_{3-\delta}$ or $\mathrm{LaBaCO}_{2} \mathrm{O}_{5+\delta}$ are included at the bottom of each figure.

The DC conductivity of $\mathrm{La}_{0.5} \mathrm{Ba}_{0.5} \mathrm{CoO}_{3-\delta}$ and $\mathrm{LaBaCo}_{2} \mathrm{O}_{5+\delta}$ as a function of temperature in $\mathrm{N}_{2}$, air and $\mathrm{O}_{2}$ is shown in Figure 7. Both materials have a high electronic conductivity $(\sim 1000$ and $500 \mathrm{~S} \mathrm{~cm}^{-1}$ at $500{ }^{\circ} \mathrm{C}$ for $\mathrm{La}_{0.5} \mathrm{Ba}_{0.5} \mathrm{CoO}_{3-\delta}$ and $\mathrm{LaBaCo}_{2} \mathrm{O}_{5+\delta}$, respectively) in air and $\mathrm{O}_{2}$. The conductivity decreases with increasing temperature, pointing to a metallic behavior, at least at low temperature where thermal reduction will not contribute. The conductivities remain high ( $\sim 300$ and $175 \mathrm{~S} \mathrm{~cm}^{-1}$ at $500{ }^{\circ} \mathrm{C}$ for $\mathrm{La}_{0.5} \mathrm{Ba}_{0.5} \mathrm{CoO}_{3-\delta}$ and $\mathrm{LaBaCo}_{2} \mathrm{O}_{5+\delta}$, respectively) in $\mathrm{N}_{2}$. In this case, the conductivity increases with temperature at lower temperatures $\left(100{ }^{\circ} \mathrm{C}-400{ }^{\circ} \mathrm{C}\right)$ and is nearly constant at higher temperatures. In addition, the layered perovskite shows nearly half of the conductivity 
relative to the cubic perovskite, which demonstrate that the A-site cation ordering is not beneficial for the overall electronic conductivity.

Table 1. Crystallographic data at $600{ }^{\circ} \mathrm{C}$ of cubic $\mathrm{La}_{0.5} \mathrm{Ba}_{0.5} \mathrm{CoO}_{3-\delta}$ and tetragonal $\mathrm{LaBaCo}_{2} \mathrm{O}_{5+\delta}$ in $\mathrm{O}_{2}$; and orthorhombic $\mathrm{LaBaCo}_{2} \mathrm{O}_{5+\delta}$ in $\mathrm{N}_{2}$ : lattice parameters, atomic positions, occupancies, thermal parameters $\left(\mathrm{B}_{\mathrm{eq}}\right)$ and goodness of fit $\left(\mathrm{R}_{\mathrm{wp}}\right)$.

\begin{tabular}{|c|c|c|c|c|c|c|c|c|c|c|}
\hline $\begin{array}{l}\text { Space } \\
\text { Group }\end{array}$ & Lattice Par. (§̊) & Atom & $\mathbf{x}$ & $\mathbf{y}$ & $\mathbf{z}$ & Occ & $\mathbf{B}_{\text {eq }}$ & $\mathbf{R}_{\mathbf{w p}}$ & $\mathbf{R}_{\exp }$ & $\chi^{2}$ \\
\hline \multirow[t]{4}{*}{$P m \overline{3} m$} & $a=3.9410(2)$ & $\mathrm{La}$ & 0 & 0 & 0 & 0.5 & $3.8(1)$ & 3.2 & 2.72 & 1.18 \\
\hline & & $\mathrm{Ba}$ & 0 & 0 & 0 & 0.5 & $3.8(1)$ & & & \\
\hline & & $\mathrm{Co}$ & 0.5 & 0.5 & 0.5 & 1 & $2.7(2)$ & & & \\
\hline & & $\mathrm{O}$ & 0 & 0.5 & 0.5 & 1 & $4.8(2)$ & & & \\
\hline \multirow[t]{6}{*}{$\mathrm{P} 4 / \mathrm{mmm}$} & $a=3.9633(2)$ & $\mathrm{La}$ & 0 & 0 & 0 & 1 & $3.9(1)$ & 3.38 & 2.70 & 1.25 \\
\hline & $c=7.7928$ & $\mathrm{Ba}$ & 0 & 0 & 0.5 & 1 & $3.9(1)$ & & & \\
\hline & & $\mathrm{Co}$ & 0.5 & 0.5 & $0.253(6)$ & 1 & $3.0(1)$ & & & \\
\hline & & O1 & 0.5 & 0.5 & 0 & 1 & $6.7(3)$ & & & \\
\hline & & $\mathrm{O} 2$ & 0 & 0.5 & $0.234(8)$ & 1 & $6.7(3)$ & & & \\
\hline & & $\mathrm{O} 3$ & 0.5 & 0.5 & 0.5 & 1 & $6.7(3)$ & & & \\
\hline \multirow[t]{10}{*}{ Pmmm } & $a=4.0001(2)$ & $\mathrm{La}$ & 0.5 & $0.252(5)$ & 0 & 1 & $3.3(2)$ & 4.18 & 3.12 & 1.61 \\
\hline & $b=7.9340$ & $\mathrm{Ba}$ & 0.5 & $0.251(4)$ & 0.5 & 1 & $3.3(2)$ & & & \\
\hline & $c=7.7942$ & Co1 & 0 & 0 & $0.253(7)$ & 1 & $2.8(2)$ & & & \\
\hline & & $\mathrm{Co} 2$ & 0 & 0.5 & $0.240(6)$ & 1 & $2.8(2)$ & & & \\
\hline & & $\mathrm{O} 1$ & 0 & $0.244(20)$ & $0.204(5)$ & 1 & $3.7(4)$ & & & \\
\hline & & $\mathrm{O} 2$ & 0.5 & 0 & $0.22(3)$ & 1 & $3.7(4)$ & & & \\
\hline & & $\mathrm{O} 3$ & 0.5 & 0.5 & $0.22(3)$ & 1 & $3.7(4)$ & & & \\
\hline & & O4 & 0 & 0 & 0.5 & 1 & $3.7(4)$ & & & \\
\hline & & O5 & 0 & 0.5 & 0.5 & 1 & $3.7(4)$ & & & \\
\hline & & O6 & 0 & 0.5 & 0 & 1 & $3.7(4)$ & & & \\
\hline
\end{tabular}
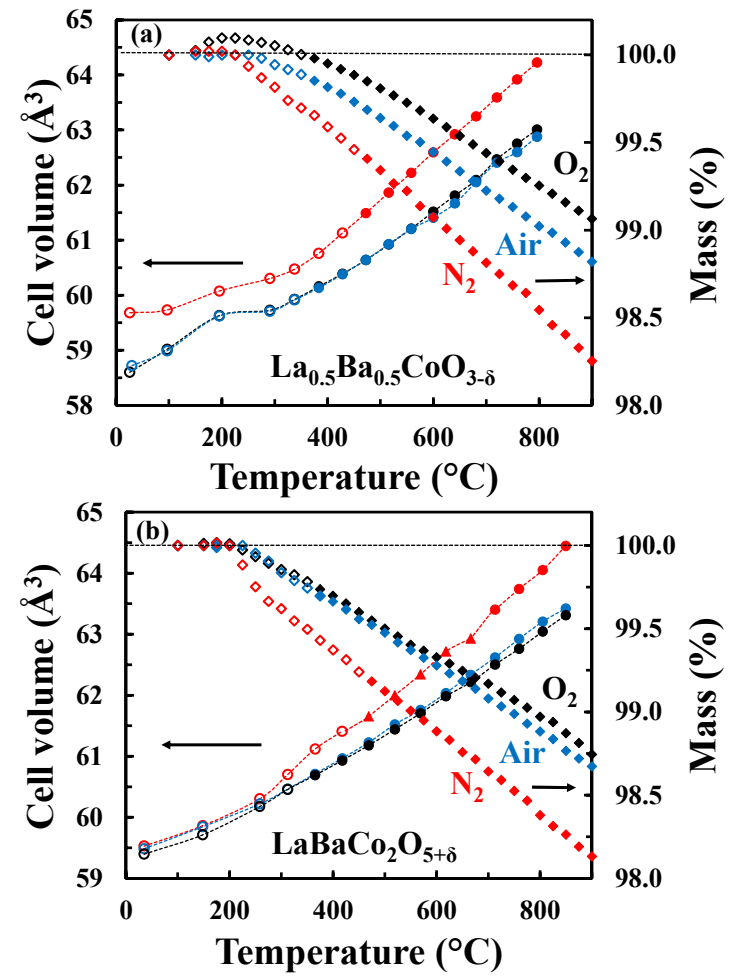

Figure 5. Unit cell volume (circles for tetragonal polymorph and triangles for orthorhombic polymorph) and relative mass change (diamonds) of (a) $\mathrm{La}_{0.5} \mathrm{Ba}_{0.5} \mathrm{CoO}_{3-\delta}$ and (b) $\mathrm{LaBaCo}_{2} \mathrm{O}_{5+\delta}$ as a function of temperature in $\mathrm{O}_{2}$ (black symbols), air (blue symbols) and $\mathrm{N}_{2}$ (red symbols). Open symbols represent data out of thermodynamic equilibrium. The dotted lines are guides to the eye. 


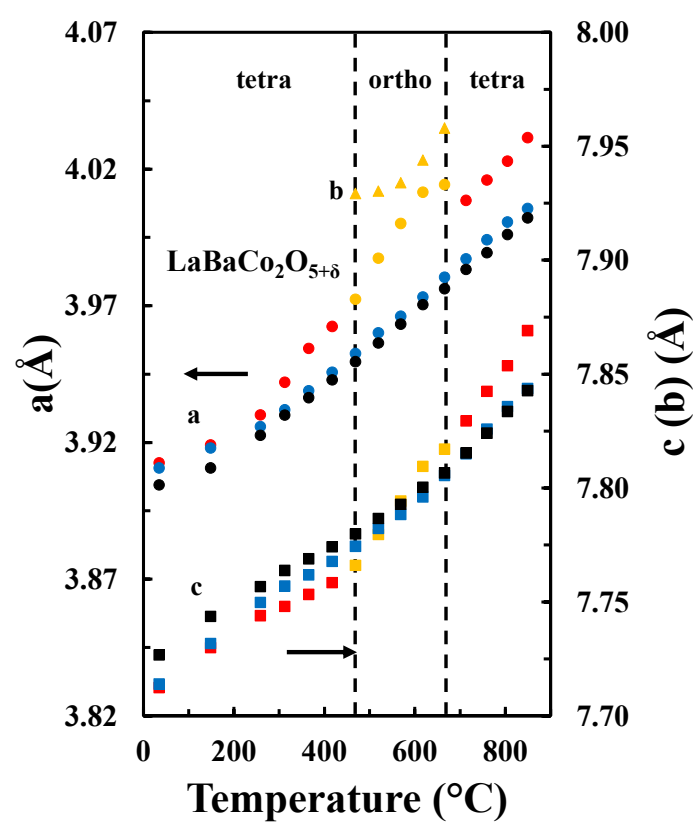

Figure 6. $a$ (circles) and $c$ (squares) tetragonal cell parameters and $a$ (orange circles), $b$ (orange triangles) and $c$ (orange squares) orthorhombic cell parameters as a function of temperature in $\mathrm{O}_{2}$ (black), air (blue) and $\mathrm{N}_{2}$ (red and orange) for $\mathrm{LaBaCO}_{2} \mathrm{O}_{5+\delta}$.

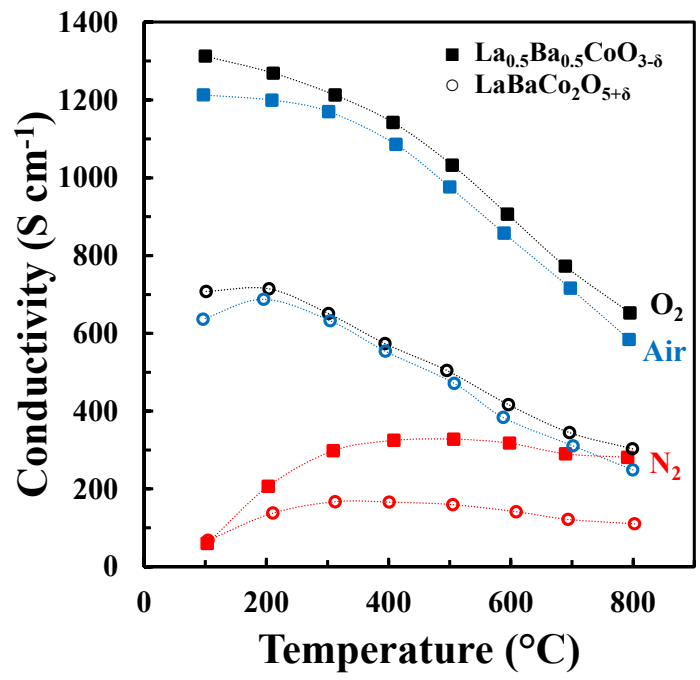

Figure 7. Four-point DC conductivity as a function of temperature for $\mathrm{La}_{0.5} \mathrm{Ba}_{0.5} \mathrm{CoO}_{3-\delta}$ (closed squares) and $\mathrm{LaBaCo}_{2} \mathrm{O}_{5+\delta}$ (open circles) in $\mathrm{O}_{2}$ (black), air (blue) and $\mathrm{N}_{2}$ (red). The dotted lines are guides to the eye.

\section{Discussion}

\subsection{Crystal Structure: Ordering Effects}

Despite the high potential of $\mathrm{La}_{0.5} \mathrm{Ba}_{0.5} \mathrm{CoO}_{3+\delta}$ and $\mathrm{LaBaCo}_{2} \mathrm{O}_{5+\delta}$ to be used as SOFC cathodes [30,31], detailed studies of the thermal evolution of crystal structure and point defects at the SOFC operational temperatures have not appeared in literature to the best of our knowledge. This is probably due to the difficulties in synthesizing single phase $\mathrm{LaBaCo}_{2} \mathrm{O}_{5+\delta}$. Kim et al. [32] studied high temperature crystal structures of equivalent $L n \mathrm{BaCo}_{2} \mathrm{O}_{5+\delta}$ materials with $\mathrm{Ln}=\mathrm{La}, \mathrm{Pr}, \mathrm{Nd}$ 
and Sm where $\mathrm{Ln}=\mathrm{La}$ was not reported as A-site cation ordered material but disordered with a cubic $\operatorname{Pm} \overline{3} m$ structure.

Here we confirmed that the layered double perovskite $\mathrm{LaBaCo}_{2} \mathrm{O}_{5+\delta}$ can be synthesized by thermal treatment of the single perovskite $\mathrm{La}_{0.5} \mathrm{Ba}_{0.5} \mathrm{CoO}_{3-\delta}$ at the appropriate temperature and $\mathrm{pO}_{2}$ conditions. Figure 8 shows the different crystal structures of the single perovskite $\mathrm{La}_{0.5} \mathrm{Ba}_{0.5} \mathrm{CoO}_{3-\delta}$ and the layered double perovskite $\mathrm{LaBaCo}_{2} \mathrm{O}_{5+\delta}$ adopt as a function of the A-site cation and/or anion ordering schemes. King et al. [11] reported that one driving force for A-site cation ordering in $L n_{0.5} \mathrm{Ba}_{0.5} \mathrm{MO}_{3-\delta}$ is the reduction of $M$, the loss of oxygen from the lattice and the creation of oxygen vacancies. The point defect equilibrium that describes the formation of oxygen vacancies, using Kröger-Vink notation [33], is:

$$
2 \mathrm{Co}_{\mathrm{Co}}+\mathrm{O}_{\mathrm{O}}^{x} \rightarrow 2 \mathrm{Co}_{\mathrm{Co}}^{x}+V_{\ddot{O}}+\frac{1}{2} \mathrm{O}_{2}(g)
$$

where the double positively effective charged oxygen vacancies are denoted as $V_{\ddot{O}}$, positively effective charged $\mathrm{Co}_{\mathrm{Co}}$ is $\mathrm{Co}^{4+}$ at the cobalt site and neutrally effective charged $\mathrm{Co}_{\mathrm{Co}}^{x}$ is $\mathrm{Co}^{3+}$ at the cobalt site.
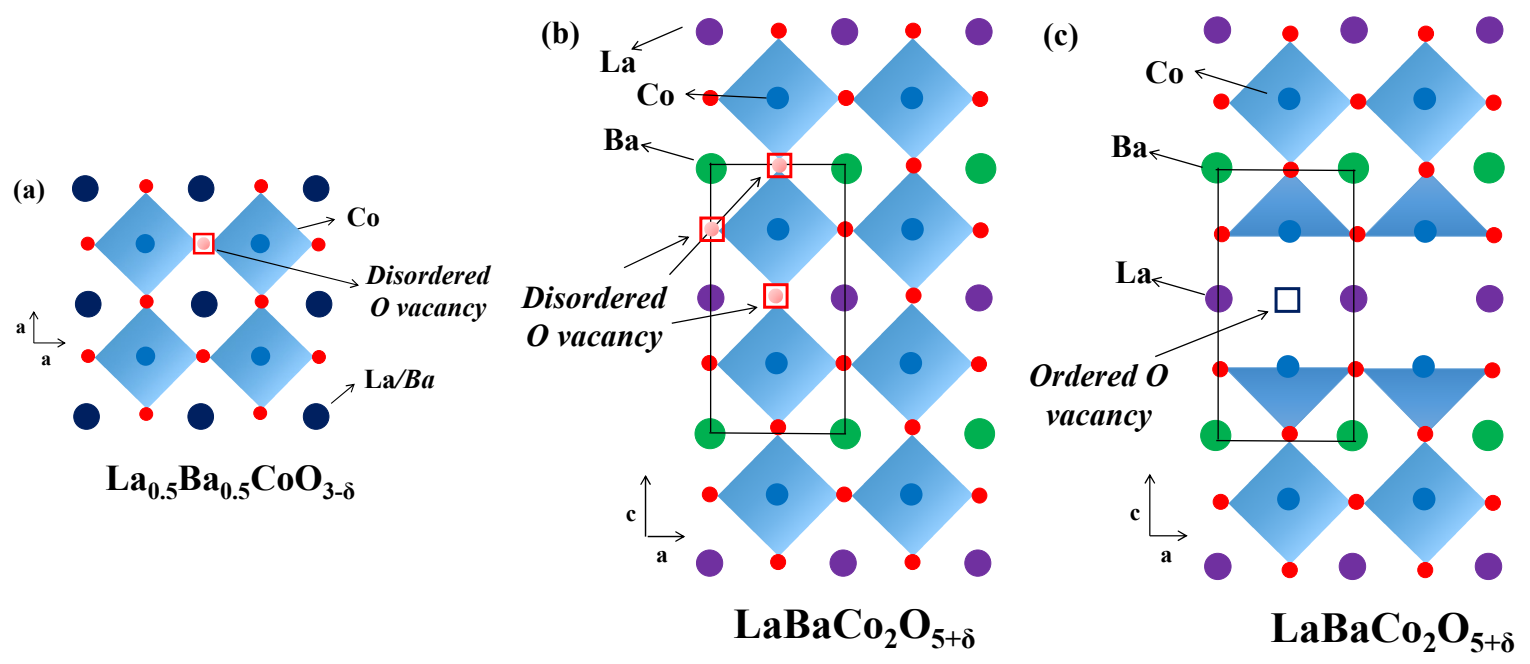

Figure 8. Crystal structure representation of: (a) cubic $P m \overline{3} m$ single perovskite $\mathrm{La}_{0.5} \mathrm{Ba}_{0.5} \mathrm{CoO}_{3-\delta}$; (b) tetragonal $\mathrm{P} 4 / \mathrm{mmm}$ A-site cation ordered and oxygen vacancy disordered $\mathrm{LaBaCO}_{2} \mathrm{O}_{5-\delta}$; and (c) orthorhombic Pmmm both A-site cation and oxygen vacancy ordered $\mathrm{LaBaCo}_{2} \mathrm{O}_{5}-\delta$. Dark blue circles are indistinguishable La/Ba atoms, violet balls are La atoms, green balls are Ba atoms, light blue balls are Co atoms, red balls are oxygen, disordered oxygen vacancies are red squares and ordered oxygen vacancies are violet squares.

The oxygen content is critical to promote A-site cation ordering in $\mathrm{LaBaCo}_{2} \mathrm{O}_{5+\delta}[15,34,35]$, but the necessary level of oxygen vacancies that is needed in order to promote A-site cation ordering is not clear from previous studies. Here, we obtained the A-site cation ordered $\mathrm{LaBaCo}_{2} \mathrm{O}_{5+\delta}$ from the disordered $\mathrm{La}_{0.5} \mathrm{Ba}_{0.5} \mathrm{CoO}_{3-\delta}$. The critical oxygen vacancy concentration at which the layered double perovskite becomes thermodynamically favorable can be estimated by the TGA data of $\mathrm{La}_{0.5} \mathrm{Ba}_{0.5} \mathrm{CoO}_{3-\delta}$ in $\mathrm{N}_{2}$ (conditions at which $\mathrm{LaBaCo}_{2} \mathrm{O}_{5+\delta}$ was synthesized). This oxygen content is $\sim 2.64$ at $1100{ }^{\circ} \mathrm{C}$, which leads to an average oxidation state for $\mathrm{Co}$ of $+2.8\left(20 \% \mathrm{Co}^{2+}+80 \% \mathrm{Co}^{3+}\right)$. Therefore, the ability of the material to adopt such a high level of oxygen vacancies can be the origin of the A-site cation ordering.

The A-site cation ordered structure can accommodate oxygen vacancies without extensive chemical expansion as shown in Figure 9, where the cell volumes and the oxygen contents vs. temperature in $\mathrm{O}_{2}$ for both $\mathrm{La}_{0.5} \mathrm{Ba}_{0.5} \mathrm{CoO}_{3-\delta}$ and $\mathrm{LaBaCo}_{2} \mathrm{O}_{5+\delta}$ materials are represented. The unit cell volumes of the two materials are quite similar despite the difference in oxygen deficiency. 


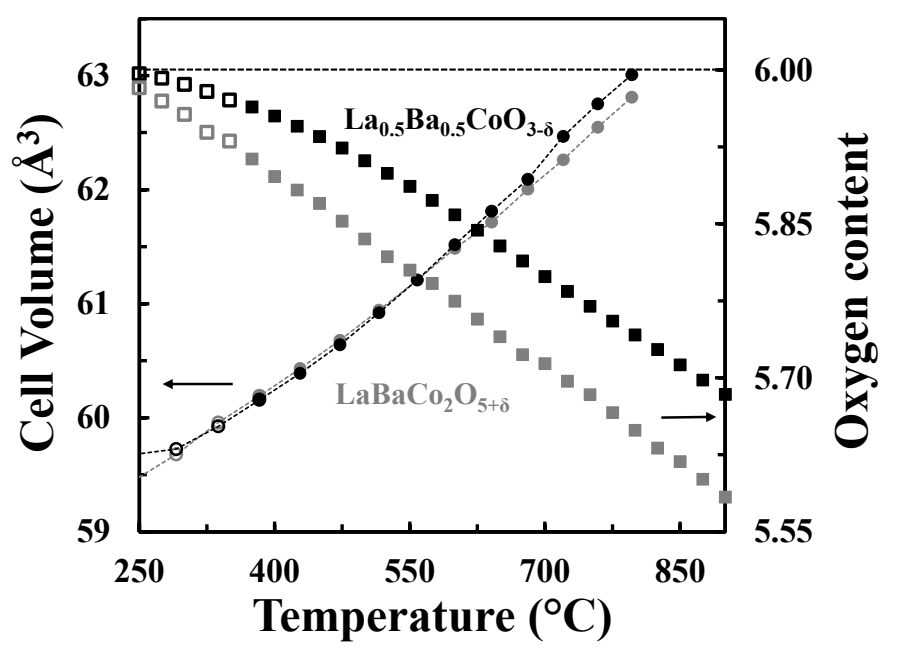

Figure 9. Cell volumes (circles) and oxygen contents (squares) versus temperature for $\mathrm{La}_{0.5} \mathrm{Ba}_{0.5} \mathrm{CoO}_{3-\delta}$ (black) and $\mathrm{LaBaCO}_{2} \mathrm{O}_{5+\delta}$ (grey) in $\mathrm{O}_{2}$. The oxygen content is with respect to the LDP. The dotted lines are guides to the eye.

A schematic phase stability diagram for the phase transition from the disordered $\mathrm{La}_{0.5} \mathrm{Ba}_{0.5} \mathrm{CoO}_{3-\delta}$ to the ordered $\mathrm{LaBaCO}_{2} \mathrm{O}_{5+\delta}$ is illustrated in Figure 10. The cation ordering is stabilized at high temperature and low partial pressure of oxygen relative to the cation disordered phase. At high level of oxygen deficiency, the material prefers to adopt a cation ordered layered structure in order to compensate for the oxygen vacancy formation. At lower temperatures and higher oxygen pressure, $\mathrm{LaBaCo}_{2} \mathrm{O}_{5+\delta}$ is metastable relative to $\mathrm{La}_{0.5} \mathrm{Ba}_{0.5} \mathrm{CoO}_{3-\delta}$. The average oxidation state of $\mathrm{Co}$ and the oxygen vacancy concentration are therefore higher in the metastable state (Figure 9).

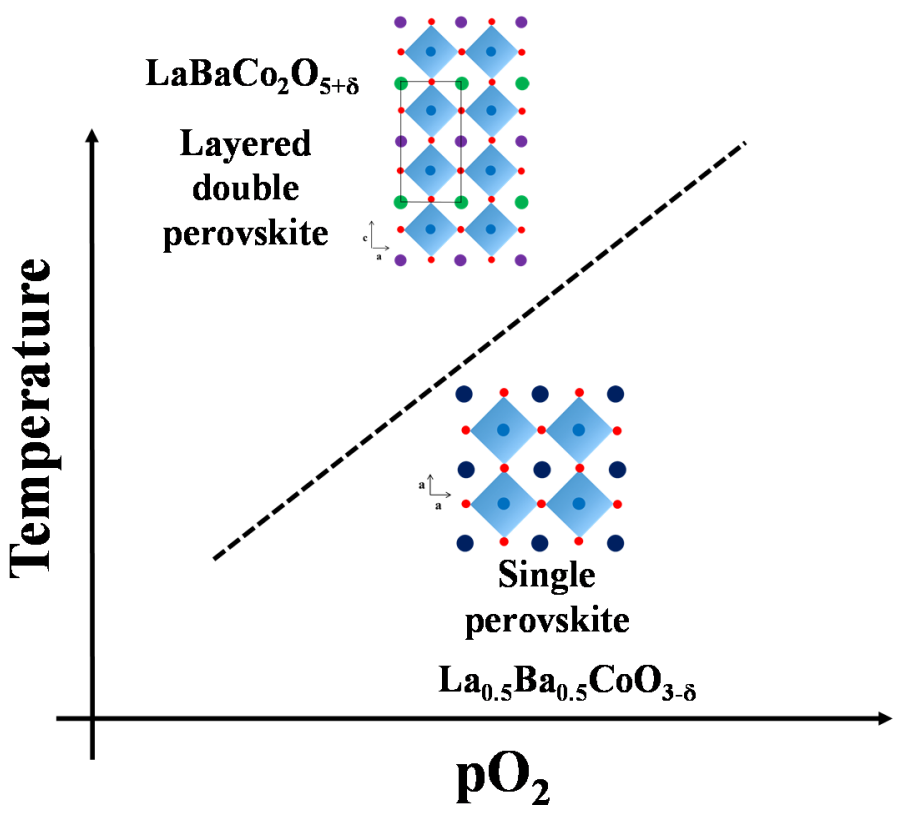

Figure 10. Schematic stability diagram for $\mathrm{La}_{0.5} \mathrm{Ba}_{0.5} \mathrm{CoO}_{3-\delta}$ and $\mathrm{LaBaCo}_{2} \mathrm{O}_{5-\delta}$ as a function of temperature and $\mathrm{pO}_{2}$.

The oxygen vacancy content determines the crystal structure of $L n B a M_{2} \mathrm{O}_{5+\delta}$. The orthorhombic symmetry is generally induced in $L n \mathrm{BaCo}_{2} \mathrm{O}_{5+\delta}$ with an oxygen content about 5.5 and temperatures below $500{ }^{\circ} \mathrm{C}$ [13]. Tsvetkov et al. [36] reported a similar behavior for $\mathrm{PrBaCo}_{2} \mathrm{O}_{5+\delta}$ where a transition from $\mathrm{P} 4 / \mathrm{mmm}$ to $\mathrm{Pmmm}$ was observed at low $\mathrm{pO}_{2}, 500{ }^{\circ} \mathrm{C}$ and 5.5 in oxygen content. For oxygen 
contents below 5.5, a larger tetragonal cell with a $3 a_{p} \times 3 a_{p} \times 2 a_{p}$ supercell is adopted [37]. Transition from a tetragonal structure to an orthorhombic structure with a later transition to the original tetragonal structure together with the oxygen content variation is shown in Figure 11. The first transition from $\mathrm{P} 4 / \mathrm{mmm}$ to Pmmm space groups is proposed to be due to the ordering of the oxygen vacancies upon heating (under conditions where the vacancy concentration is increasing), while the transition from Pmmm to P4/mmm corresponds to the order-disorder transition of the oxygen vacancies as reported by Kim et al. for similar materials [32]. The oxygen vacancy ordering depends both on the oxygen contents and temperatures and is typically observed for oxygen content between 5.65 and 5.70 and in the temperature range $450{ }^{\circ} \mathrm{C}-650{ }^{\circ} \mathrm{C}$. Although it has been proposed in $\operatorname{LnBaM} \mathrm{Ba}_{5+\delta}$ that A-site cation ordering is promoted by oxygen vacancy formation [11] and that the substitution of $\mathrm{Ba}$ by $\mathrm{Sr}$ reduces the tendency to form ordered materials [38-40], the driving force for oxygen vacancy ordering is still a matter of discussion. We propose that a stronger tendency for oxygen vacancy ordering will be promoted as the difference in size between $L n$ and Ba becomes larger in order to more easily compensate for the difference of size between them. The ordering results in location of the oxygen vacancies in the $L n \mathrm{O}$ layer $[15,29]$. Furthermore, the level of oxygen deficiency is strongly dependent on the size and type of lanthanide at the A-site and, as La is the largest lanthanide element, we propose that the oxygen deficiency does not have to be as large as 5.5 as in $\mathrm{PrBaCo}_{2} \mathrm{O}_{5+\delta}$ [36] in order to compensate for the size difference.

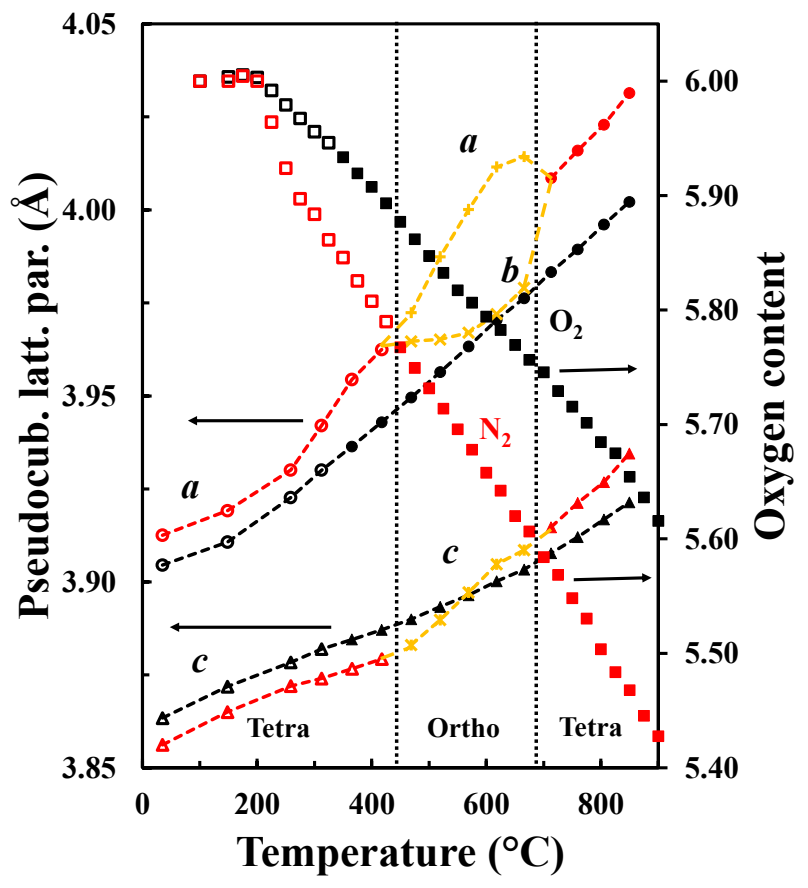

Figure 11. $a$ (circles) and $c$ (triangles) pseudocubic tetragonal lattice parameters as well as $a$ (plusses), $b$ (crosses) and $c$ (crossed plusses) pseudocubic orthorhombic lattice parameters and oxygen content (squares) versus temperature of $\mathrm{LaBaCO}_{2} \mathrm{O}_{5+\delta}$ in $\mathrm{O}_{2}$ (black) and $\mathrm{N}_{2}$ (red). The transitions tetragonal-orthorhombic-tetragonal are shown. Open symbols are data out of the equilibrium. The hatched lines are guides to the eye.

\subsection{Thermal/Chemical Expansion and Electrical Conductivity}

High thermal as well as chemical expansions are among the main challenges in order to utilize $\mathrm{La}_{0.5} \mathrm{Ba}_{0.5} \mathrm{CoO}_{3+\delta}$ and $\mathrm{LaBaCo}_{2} \mathrm{O}_{5+\delta}$ as SOFC cathodes. Thermal expansion coefficients (TEC) calculated from linear fit of the cell parameters in $\mathrm{O}_{2}$ and $\mathrm{N}_{2}$ are summarized in Table 2 for both materials. The A-site cation ordering does not have significant impact on the TEC values. TEC of $\mathrm{LaBaCo}_{2} \mathrm{O}_{5+\delta}$ is higher than for other $\mathrm{LnBaCo}_{2} \mathrm{O}_{5+\delta}$ materials such as $\mathrm{NdBaCo}_{2} \mathrm{O}_{5+\delta}$ [2] and 
$\mathrm{GdBaCo}_{2} \mathrm{O}_{5+\delta}$ [41]. The values reported for $\mathrm{La}_{0.5} \mathrm{Ba}_{0.5} \mathrm{CoO}_{3-\delta}$ are in good agreement with previous reports [7].

Table 2. Thermal expansion coefficients of the unit cell parameters $\left(\alpha_{a}\right.$ and $\left.\alpha_{c}\right)$ and the isotropic linear thermal expansion coefficient for $\mathrm{La}_{0.5} \mathrm{Ba}_{0.5} \mathrm{CoO}_{3-\delta}$ and $\mathrm{LaBaCo}_{2} \mathrm{O}_{5+\delta}$ in $\mathrm{O}_{2}$ and $\mathrm{N}_{2}$ atmospheres.

\begin{tabular}{ccccc}
\hline \multicolumn{5}{c}{$\mathrm{O}_{2}$} \\
\hline $\mathrm{Material}$ & $\mathrm{T}$ range $\left({ }^{\circ} \mathrm{C}\right)$ & $\alpha_{\mathrm{a}}\left(10^{-6} \mathrm{~K}^{-1}\right)$ & $\alpha_{\mathrm{c}}\left(10^{-6} \mathrm{~K}^{-1}\right)$ & $\alpha_{\mathrm{i}}\left(10^{-6} \mathrm{~K}^{-1}\right)$ \\
$\mathrm{La}_{0.5} \mathrm{Ba}_{0.5} \mathrm{CoO}_{3-\delta}$ & $\mathrm{RT}-250$ & $19 \pm 1$ & \\
$\mathrm{LaBaCo}_{2} \mathrm{O}_{5+\delta}$ & $300-800$ & $31.3 \pm 0.1$ & \\
& $\mathrm{RT}-200$ & $13 \pm 1$ & $18 \pm 1$ & $15 \pm 1$ \\
& $250-750$ & $34.6 \pm 0.2$ & $16.1 \pm 0.3$ & $29.3 \pm 0.3$ \\
& $800-850$ & $36.4 \pm 0.2$ & $25.2 \pm 0.3$ & $32.8 \pm 0.3$ \\
\hline $\mathrm{Material}_{0.5}$ & \multicolumn{5}{c}{$\mathrm{Na}_{0.5} \mathrm{CoO}_{3-\delta}$} & $\mathrm{T}$ range $\left({ }^{\circ} \mathrm{C}\right)$ & $\alpha_{\mathrm{a}}\left(10^{-6} \mathrm{~K}^{-1}\right)$ & $\alpha_{\mathrm{c}}\left(10^{-6} \mathrm{~K}^{-1}\right)$ & $\alpha_{\mathrm{i}}\left(10^{-6} \mathrm{~K}^{-1}\right)$ \\
$\mathrm{LaBaCo}_{2} \mathrm{O}_{5+\delta}$ & $\mathrm{RT}-250$ & $15 \pm 1$ & & \\
& $300-800$ & $37.4 \pm 0.3$ & & \\
& $\mathrm{RT}-200$ & $20 \pm 1$ & $18 \pm 1$ & $20 \pm 1$ \\
& $250-400$ & $50.9 \pm 0.5$ & $13.6 \pm 0.4$ & $38.4 \pm 7.1$ \\
& $450-650$ & $53.0 \pm 2.6$ & $33.2 \pm 0.8$ & $39.3 \pm 8.5$ \\
& $700-850$ & $41.9 \pm 0.5$ & $37.1 \pm 0.6$ & $40.3 \pm 5.4$ \\
\hline
\end{tabular}

As it was discussed in the previous section, the pseudocubic lattice parameters and the oxygen content of $\mathrm{LaBaCO}_{2} \mathrm{O}_{5+\delta}$ as a function of temperature in both $\mathrm{O}_{2}$ and $\mathrm{N}_{2}$ are shown in Figure 11. The corresponding change in the oxygen deficiency is also included in the figure. An anisotropic chemical expansion evolves at the onset of thermal reduction. The thermal reduction occurs at temperatures as low as $250{ }^{\circ} \mathrm{C}$. Chemical expansion coefficient can be estimated from the combination of the unit cell parameters and the oxygen non-stoichiometry. The effect of chemical expansion of the lattice parameter a can be expressed through the chemical strain $\varepsilon_{c}=\frac{\left(a-a_{0}\right)}{a_{0}}=\frac{a}{a_{0}}$ where $a_{\mathrm{o}}$ is the lattice parameter in pure $\mathrm{O}_{2}$ and $a$ is the corresponding value in for example $\mathrm{N}_{2}$. Correspondingly the normalized chemical strain [42] can be defined as $\frac{\varepsilon_{c}}{\delta}$ where $\Delta \delta$ is the difference in oxygen non-stoichiometry by the change in atmosphere at constant temperature. The chemical strain calculated from the data in Figure 11 are summarized in Table 3 . The chemical strain is relatively independent on temperature for both $\mathrm{La}_{0.5} \mathrm{Ba}_{0.5} \mathrm{CoO}_{3-\delta}$ and $\mathrm{LaBaCo}_{2} \mathrm{O}_{5+\delta}$. The chemical expansion of $\mathrm{La}_{0.5} \mathrm{Ba}_{0.5} \mathrm{CoO}_{3-\delta}$ is larger than for the A-site cation ordered $\mathrm{LaBaCO}_{2} \mathrm{O}_{5+\delta}$ as it can be seen for the cell volume values in Table 3. In addition, the chemical expansion of the A-site cation ordered $\mathrm{LaBaCo}_{2} \mathrm{O}_{5+\delta}$ is anisotropic. The chemical expansion of $\mathrm{LaBaCo}_{2} \mathrm{O}_{5+\delta}$ in the $a$ direction is larger than in the $c$ direction but comparable with the chemical expansion of $\mathrm{La}_{0.5} \mathrm{Ba}_{0.5} \mathrm{CoO}_{3-\delta}$ in the $a$ direction. Therefore, this anisotropy could be at the origin of the reduction of the chemical expansion for the A-site cation ordered $\mathrm{LaBaCO}_{2} \mathrm{O}_{5+\delta}$ material.

Table 3. Normalized chemical strain values for $\mathrm{La}_{0.5} \mathrm{Ba}_{0.5} \mathrm{CoO}_{3-\delta}$ and $\mathrm{LaBaCo}_{2} \mathrm{O}_{5+\delta}$.

\begin{tabular}{ccccc}
\hline & \multicolumn{3}{c}{$\mathbf{L a B a C o}_{\mathbf{2}} \mathbf{O}_{5+\delta}$} & $\mathbf{L a}_{\mathbf{0 . 5}} \mathbf{B a}_{\mathbf{0} .5} \mathbf{C o O}_{3-\delta}$ \\
\cline { 2 - 5 } & \multicolumn{3}{c}{ Chemical Strain } & Chemical Strain \\
\hline $\mathrm{T}\left({ }^{\circ} \mathrm{C}\right)$ & $(\Delta \mathrm{a} / \mathrm{ao}) / \Delta \delta$ & $(\Delta \mathrm{c} / \mathrm{co}) / \Delta \delta$ & $1 / 3(\Delta \mathrm{V} / \mathrm{Vo}) / \Delta \delta$ & $(\Delta \mathrm{a} / \mathrm{ao}) / \Delta \delta$ \\
\hline 450 & $0.05 \pm 0.01$ & $-0.02 \pm 0.01$ & $0.02 \pm 0.01$ & $0.07 \pm 0.01$ \\
550 & $0.07 \pm 0.01$ & $0.01 \pm 0.01$ & $0.03 \pm 0.01$ & $0.07 \pm 0.01$ \\
650 & $0.06 \pm 0.01$ & $0.01 \pm 0.01$ & $0.03 \pm 0.01$ & $0.07 \pm 0.01$ \\
750 & $0.04 \pm 0.01$ & $0.01 \pm 0.01$ & $0.03 \pm 0.01$ & $0.05 \pm 0.01$ \\
850 & $0.04 \pm 0.01$ & $0.02 \pm 0.01$ & $0.03 \pm 0.01$ & $0.06 \pm 0.01$ \\
\hline
\end{tabular}


Tsvetkov et al. [36] also reported an anisotropic chemical expansion at high temperatures for $\operatorname{PrBaCo}{ }_{2} \mathrm{O}_{5+\delta}$. However, in this case both $a$ and $c$ parameters balance out the total chemical expansion leading to a linear increase of the cell volume with no contribution of the chemical expansion to the total expansion. However, for $\mathrm{LaBaCo}_{2} \mathrm{O}_{5+\delta}$ evidenced from the cell volume parameter, the expansion of the $a$ parameter dominates the global chemical expansion as the cell volume increases with temperature (Figure $5 b$ ).

The thermal and chemical expansion coefficients of both $\mathrm{La}_{0.5} \mathrm{Ba}_{0.5} \mathrm{CoO}_{3-\delta}$ and $\mathrm{LaBaCo}_{2} \mathrm{O}_{5+\delta}$ can also be compared with other cobaltite materials. $\mathrm{LaCoO}_{3}$ has a thermal expansion coefficient slightly lower than the two materials studied in this work [43]. Chen et al. [44] reported thermal and chemical expansion coefficients for analogous cobaltites with $\mathrm{Sr}$ instead of $\mathrm{Ba}$ on the A-site: $\mathrm{La}_{1-x} \mathrm{Sr}_{x} \mathrm{CoO}_{3-\delta}$ with $\mathrm{x}=0.3$ and 0.4 . For $\mathrm{x}=0.4$, both thermal and chemical expansion coefficients are lower than the values for $\mathrm{La}_{0.5} \mathrm{Ba}_{0.5} \mathrm{CoO}_{3-\delta}$ and $\mathrm{LaBaCo}_{2} \mathrm{O}_{5+\delta}$.

At temperatures below $\sim 400{ }^{\circ} \mathrm{C}$, the electrical conductivity of $\mathrm{La}_{0.5} \mathrm{Ba}_{0.5} \mathrm{CoO}_{3-\delta}$ and $\mathrm{LaBaCo}_{2} \mathrm{O}_{5+\delta}$ is decreasing with temperature and the materials show a metallic type behavior (Figure 7). Above this temperature region, the electric conductivity of $\mathrm{La}_{0.5} \mathrm{Ba}_{0.5} \mathrm{CoO}_{3-\delta}$ and $\mathrm{LaBaCo}_{2} \mathrm{O}_{5+\delta}$ is consistent with previous reports on p-type semiconductor behavior [32-34]. Assuming $\mathrm{LaCoO}_{3}$ as the host material, substitution of $\mathrm{Ba}$ into $\mathrm{LaCoO}_{3}$ can be described by defect equilibrium (2), using Kröger-Vink notation [33]:

$$
\mathrm{BaCoO}_{3} \stackrel{\mathrm{LaCoO}_{3}}{\rightarrow} \mathrm{Ba}_{\mathrm{La}}^{\prime}+\mathrm{Co}_{\mathrm{Co}}+3 \mathrm{O}_{\mathrm{O}}^{x}
$$

where the negatively effective charged $B a_{L a}^{\prime}$ represents $\mathrm{Ba}^{2+}$ on $\mathrm{La}^{3+}$ sites and the positively effective charged $\mathrm{Co}_{\mathrm{Co}}$ represents the change of oxidation state of $\mathrm{Co}$ from $\mathrm{Co}^{3+}$ in $\mathrm{LaCoO}_{3}$ to $\mathrm{Co}^{4+}$ in $\mathrm{BaCoO}_{3}$. $\mathrm{Co}_{\mathrm{Co}}$ is inferred as the dominating charge carrier explaining the p-type semiconducting behavior. The concentration of $\mathrm{Co}_{\mathrm{Co}}$ is strongly affected by the thermal reduction of $\mathrm{Co}$, as described by defect equilibrium (1).

The change in the electronic conductivity is caused by the change in carrier concentration and the increased charge carrier mobility with increasing temperature. The fraction of $\mathrm{Co}^{4+}$ and the concentration of active charge carriers $\mathrm{Co}_{C_{0}}$, for $\mathrm{La}_{0.5} \mathrm{Ba}_{0.5} \mathrm{CoO}_{3-\delta}$ and $\mathrm{LaBaCo}_{2} \mathrm{O}_{5+\delta}$ calculated from the oxygen non-stoichiometry are plotted in Figure 12 together with the electrical conductivity. The fraction of $\mathrm{Co}^{4+}$ is strongly reduced with increasing temperature and the reduction in the electrical conductivity in $\mathrm{O}_{2}$ and air at elevated temperatures where thermal reduction occur can be rationalized by the fast reduction of charge carriers with increasing temperature. However, in $\mathrm{N}_{2}$, the electrical conductivity is almost constant and independent of temperature even though the change in the concentration of the major charge carrier $\left(\mathrm{Co}_{\mathrm{CO}_{0}}\right)$ is more abrupt here relative to the more oxidizing conditions. The electrical conductivity of $\mathrm{La}_{0.5} \mathrm{Ba}_{0.5} \mathrm{CoO}_{3-\delta}$ and $\mathrm{LaBaCo}_{2} \mathrm{O}_{5+\delta}$ in $\mathrm{N}_{2}$ cannot be qualitative explained by only considering the concentration in the major change carrier.

The logarithm of electrical conductivity is plotted as a function of the logarithmic partial pressure of oxygen in Figure 13. The electrical conductivity is decreasing with reducing partial pressure of oxygen in line with p-type conductivity inferred from the two proposed defect equilibria (1) and (2). However, the slope of $\log \sigma$ is significantly different from $1 / 4$ expected for the region where $B a_{L a}^{\prime}$ is mainly charge compensated by $\mathrm{Co}_{\mathrm{Co}}$ and $V_{\ddot{\mathrm{O}}}$ and neglecting the contribution from ionic conductivity. Moreover, in $\mathrm{N}_{2}$ the fraction of $\mathrm{Co}^{4+}$ approaches zero and one should expect the conductivity to become quite low. Based on the electrical conductivity of acceptor-doped $\mathrm{LaCoO}_{3}$ [44] it is not very likely that a classical mass action type model including defect equilibria (1) and (2) and localized electrons will describe accurately the electrical conductivity of $\mathrm{Ba}$ doped $\mathrm{LaCoO}_{3}$. The electrical conductivity reported here resemble the data reported for other acceptor doped $\mathrm{LaCoO}_{3}$ materials where a gradual change from a metallic like conductivity with iterant electrons towards a polaron hopping type mechanism has been discussed [45]. 

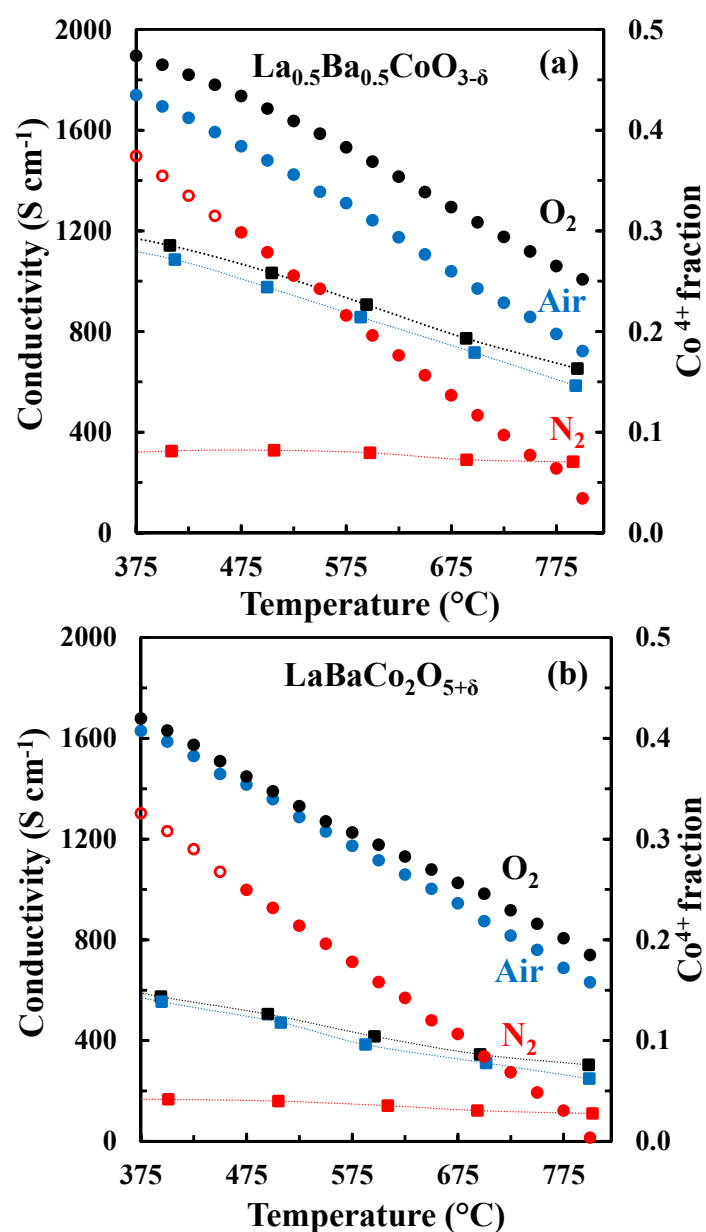

Figure 12. Electrical conductivity (squares) and $\mathrm{Co}^{4+}$ fraction (circles) vs. temperature for $\mathrm{La}_{0.5} \mathrm{Ba}_{0.5} \mathrm{CoO}_{3-\delta}$ (a) and $\mathrm{LaBaCo}_{2} \mathrm{O}_{5+\delta}(\mathbf{b})$ in $\mathrm{O}_{2}$, air and $\mathrm{N}_{2}$. The open symbols are data out of the equilibrium. The dotted lines are guides to the eye.

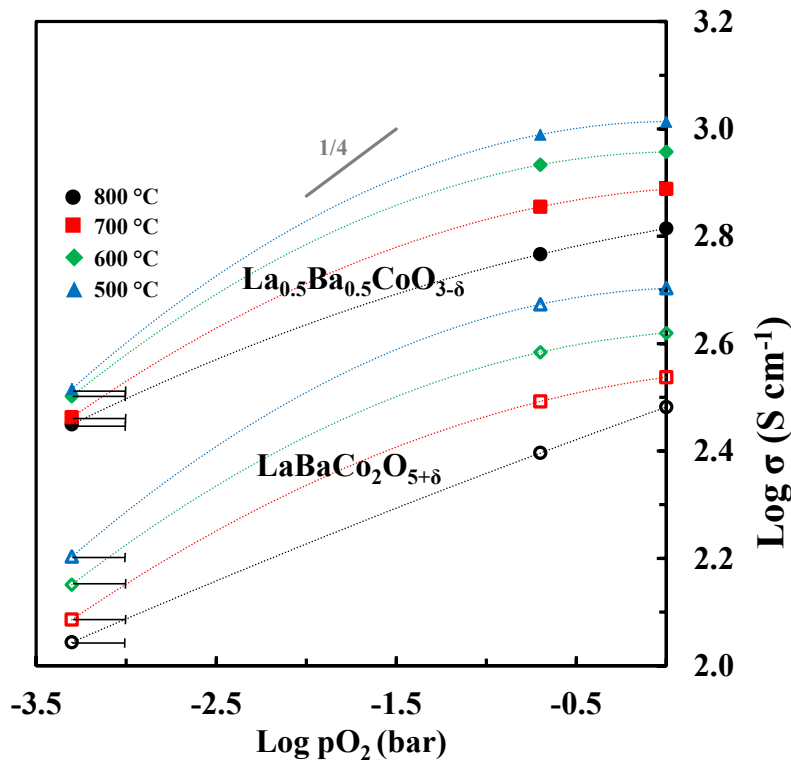

Figure 13. $\log \sigma$ vs. $\log \mathrm{pO}_{2}$ for $\mathrm{La}_{0.5} \mathrm{Ba}_{0.5} \mathrm{CoO}_{3-\delta}$ and $\mathrm{LaBaCo}_{2} \mathrm{O}_{5+\delta}$. At low $\mathrm{pO}_{2}\left(\mathrm{~N}_{2}\right)$ the uncertainty in $\mathrm{pO}_{2}$ is illustrated. The dotted lines are guides to the eye. 
The detrimental effect of the A-site cation ordering on the total electrical conductivity is also evident from the data shown in Figure 13. The lower conductivity by cation ordering can be explained by the anisotropic nature of the crystal structure accompanied by the cation ordering.

\section{Materials and Methods}

\subsection{Synthesis of the Materials}

$\mathrm{La}_{0.5} \mathrm{Ba}_{0.5} \mathrm{CoO}_{3-\delta}$ was prepared by spray pyrolysis (Cerpotech AS, Norway, purity $>99 \%$ ) of mixture of nitrate solutions containing stoichiometric amounts of the cations. The as-received powder was sequentially calcined at $1100{ }^{\circ} \mathrm{C}$ for $12 \mathrm{~h}$ in air in order to obtain a single phase. A-site cation ordered $\mathrm{LaBaCo}_{2} \mathrm{O}_{5+\delta}$ was obtained by calcination of the as-prepared powder by spray pyrolysis at $1100{ }^{\circ} \mathrm{C}$ for $12 \mathrm{~h}$ in $\mathrm{N}_{2}$. In order to control the oxygen content, both $\mathrm{La}_{0.5} \mathrm{Ba}_{0.5} \mathrm{CoO}_{3-\delta}$ and $\mathrm{LaBaCo}_{2} \mathrm{O}_{5+\delta}$ materials were finally annealed at $350{ }^{\circ} \mathrm{C}$ for $24 \mathrm{~h}$ in pure $\mathrm{O}_{2}$.

The calcined powders of both $\mathrm{La}_{0.5} \mathrm{Ba}_{0.5} \mathrm{CoO}_{3-\delta}$ and $\mathrm{LaBaCo}_{2} \mathrm{O}_{5+\delta}$ were ball milled with $5 \mathrm{~mm}$ yttria-stabilized zirconia (YSZ) balls in isopropanol for $72 \mathrm{~h}$ in order to remove possible hard agglomerates and sequentially sieved at $250 \mu \mathrm{m}$. Rectangular dense bars of typical dimensions $1 \times 5 \times 20 \mathrm{~mm}$ were obtained by uniaxially pressing $(20 \mathrm{MPa}$ ) of the sieved powders, followed by heat treatment at $1100{ }^{\circ} \mathrm{C}$ in air for $4 \mathrm{~h}$ for $\mathrm{La}_{0.5} \mathrm{Ba}_{0.5} \mathrm{CoO}_{3-\delta}$ and at $1175{ }^{\circ} \mathrm{C}$ in $\mathrm{N} 2$ for $4 \mathrm{~h}$ for $\mathrm{LaBaCo}_{2} \mathrm{O}_{5+\delta}$, achieving $90 \%$ of theoretical density.

The particle size of the powders after heat treatment was investigated by scanning electron microscopy (SEM) using a Hitatchi S-3400N instrument.

\subsection{Structural Characterization at Room and High Temperature}

Phase purity for both materials was determined using a Bruker D8 Advance DaVinci X-ray diffractometer. High temperature X-Ray diffraction (HT-XRD) measurements were performed using a Bruker D8 Advance diffractometer equipped with an MRI TCP20 high temperature camera. A Pt strip type resistive heater functioned as sample support. A temperature interval of $100{ }^{\circ} \mathrm{C}-900{ }^{\circ} \mathrm{C}$ and step size of $50{ }^{\circ} \mathrm{C}$ were used, with data collected from RT to about $800{ }^{\circ} \mathrm{C}$ under different gas atmospheres: air ( $\mathrm{pO}_{2}=0.2$ bar), $\mathrm{O}_{2}\left(\mathrm{pO}_{2}=1\right.$ bar) and $\mathrm{N}_{2}\left(\mathrm{pO}_{2} \approx 10^{-4}\right.$ bar). An S-type thermocouple was used for temperature determination using the radiant heater. XRD patterns were collected across an angular range $20^{\circ} \mathrm{C}-75^{\circ} \mathrm{C}$. Total collection time per scan at each temperature was $\sim 30 \mathrm{~min}$. The heating rate between each temperature was $0.1^{\circ} \mathrm{C} / \mathrm{s}$. After the set-temperature was reached, a dwell time of $10 \mathrm{~min}$ was used before the XRD measurement was started. The sample temperature was calibrated against separate HT-XRD of an alpha- $\mathrm{Al}_{2} \mathrm{O}_{3}$ standard. Rietveld refinements were carried out with the Bruker TOPAS software [46]. For $\mathrm{La}_{0.5} \mathrm{Ba}_{0.5} \mathrm{CoO}_{3-\delta}$ the structure at all temperatures and atmospheres was described using a cubic model $(P m \overline{3} m)$ [29]. For $\mathrm{LaBaCo}_{2} \mathrm{O}_{5+\delta}$ the structure in the $450{ }^{\circ} \mathrm{C}-675^{\circ} \mathrm{C}$ temperature range and in $\mathrm{N}_{2}$ was described using an orthorhombic model (Pmmm) [15] while for the rest of temperatures in $\mathrm{N}_{2}$ and all the temperatures in both air and $\mathrm{O}_{2}$ the structure was tetragonal $(\mathrm{P} 4 / \mathrm{mmm})$ [29]. The peak shape for each pattern was described using a modified Thomson-Cox-Hastings-pseudo-Voigt (PV-TCHZ). For each pattern independent variables consisted of five different parameters: Chebychev polynomial background function, lattice parameters, sample displacement, symmetry constrained atomic positions and isotropic thermal displacement parameters. The oxygen occupancy was fixed to stoichiometric for all the patterns.

\subsection{Thermogravimetrical Analysis}

The absolute oxygen content of $\mathrm{La}_{0.5} \mathrm{Ba}_{0.5} \mathrm{CoO}_{3-\delta}$ and $\mathrm{LaBaCo}_{2} \mathrm{O}_{5+\delta}$ was measured by means of thermogravimetric reduction in $5 \% \mathrm{H}_{2}$ in $\mathrm{N}_{2}$ at $1000{ }^{\circ} \mathrm{C}$ for $24 \mathrm{~h}$ to metallic $\mathrm{Co}$ and binary oxides $\mathrm{La}_{2} \mathrm{O}_{3}$ and $\mathrm{BaO}$. The completion of the reduction into these components was confirmed by X-Ray diffraction. The relative oxygen stoichiometry was measured by thermogravimetric measurements using a Netzsch Thermal analysis system 4 (STA449). Measurements were conducted using an $\mathrm{Al}_{2} \mathrm{O}_{3}$ 
crucible at a heating rate of $10{ }^{\circ} \mathrm{C} / \mathrm{min}$. First, the samples were heated to $250{ }^{\circ} \mathrm{C}$ and cooled to in order to eliminate any $\mathrm{CO}_{2}$ or humidity that can interfere with the measurement. Then, the samples were sequentially heated from $100{ }^{\circ} \mathrm{C}$ to $950{ }^{\circ} \mathrm{C}$ after every $25^{\circ} \mathrm{C}$, with a dwell time of $35 \mathrm{~min}$ in order to reach equilibrium. The time-temperature program corresponded to the program used for the HT-XRD experiments. Data were collected in different atmospheres: air, $\mathrm{O}_{2}$ and $\mathrm{N}_{2}$ similar to the high temperature XRD measurements were taken. The mass changes prior to the measurement of the samples were corrected for buoyancy by measurements on an empty $\mathrm{Al}_{2} \mathrm{O}_{3}$ crucible. The weight reported at each dwell temperature is the weight recorded at the end of each dwell period of $35 \mathrm{~min}$. The relative changes in the oxygen non-stoichiometry were calculated based on the TGA data.

\subsection{Electrical Conductivity}

Electrical conductivity for $\mathrm{La}_{0.5} \mathrm{Ba}_{0.5} \mathrm{CoO}_{3-\delta}$ and $\mathrm{LaBaCo}_{2} \mathrm{O}_{5+\delta}$ was determined using a four-point DC method on sintered bars, as previously described by Wærnhus et al. [47] in the same three different atmospheres that previous TGA and HT-XRD were performed: air, $\mathrm{O}_{2}$ and $\mathrm{N}_{2}$.

\section{Conclusions}

A-site cation ordered and layered double perovskite $\mathrm{LaBaCo}_{2} \mathrm{O}_{5+\delta}$ and cubic cation disordered perovskite $\mathrm{La}_{0.5} \mathrm{Ba}_{0.5} \mathrm{CoO}_{3-\delta}$ were obtained from a powder synthesized by spray pyrolysis. $\mathrm{LaBaCO}_{2} \mathrm{O}_{5+\delta}$ was prepared by thermal annealing of $\mathrm{La}_{0.5} \mathrm{Ba}_{0.5} \mathrm{CoO}_{3-\delta}$ in $\mathrm{N}_{2}$. Thermogravimetric analysis demonstrated that a critical level of oxygen vacancies is required in $\mathrm{La}_{0.5} \mathrm{Ba}_{0.5} \mathrm{CoO}_{3-\delta}$ in order to stabilize the A-site cation ordered structure. The oxygen content of $\mathrm{La}_{0.5} \mathrm{Ba}_{0.5} \mathrm{CoO}_{3-\delta}$ for obtaining A-site ordering was calculated to be $\sim 2.64$ and, therefore, $\mathrm{LaBaCo}_{2} \mathrm{O}_{5+\delta}$ is metastable with respect to $\mathrm{La}_{0.5} \mathrm{Ba}_{0.5} \mathrm{CoO}_{3-\delta}$ in oxidizing atmosphere. High temperature $\mathrm{X}$-ray diffraction between room temperature and $800{ }^{\circ} \mathrm{C}$ revealed that $\mathrm{La}_{0.5} \mathrm{Ba}_{0.5} \mathrm{CoO}_{3-\delta}$ remained cubic at the studied temperatures in $\mathrm{O}_{2}$ as well as in $\mathrm{N}_{2}$. No structural changes were observed for tetragonal A-site cation ordered $\mathrm{LaBaCo}_{2} \mathrm{O}_{5+\delta}$ in air while a change to orthorhombic structure was observed between $475{ }^{\circ} \mathrm{C}$ and $650{ }^{\circ} \mathrm{C}$ and at low $\mathrm{pO}_{2}\left(\mathrm{~N}_{2}\right)$ due to ordering of oxygen vacancies. Combining thermogravimetric analyses and high temperature $\mathrm{X}$-ray data also showed that the ordering of oxygen vacancies depends strongly on the level of oxygen deficiency and temperature. The thermal and chemical expansions of the two materials were determined using the high X-ray temperature diffraction data combined with thermogravimetrical analysis. An anisotropic chemical expansion was shown for the A-site cation ordered $\mathrm{LaBaCO}_{2} \mathrm{O}_{5+\delta}$. A high electronic conductivity for both A-site cation ordered and disordered materials in both $\mathrm{O}_{2}\left(\sim 1000\right.$ and $500 \mathrm{~S} \mathrm{~cm}^{-1}$ at $500{ }^{\circ} \mathrm{C}$ in $\mathrm{pO}_{2}=1$ bar for $\mathrm{La}_{0.5} \mathrm{Ba}_{0.5} \mathrm{CoO}_{3-\delta}$ and $\mathrm{LaBaCO}_{2} \mathrm{O}_{5+\delta}$, respectively) and $\mathrm{N}_{2}\left(\sim 300\right.$ and $175 \mathrm{~S} \mathrm{~cm}^{-1}$ at $500{ }^{\circ} \mathrm{C}$ for $\mathrm{La}_{0.5} \mathrm{Ba}_{0.5} \mathrm{CoO}_{3-\delta}$ and $\mathrm{LaBaCo}_{2} \mathrm{O}_{5+\delta}$, respectively) was evidenced. At low temperatures, a metallic-like conductivity was observed, while a p-type semiconducting conductivity behavior was evident at elevated temperatures.

Acknowledgments: Financial support from The Research Council of Norway under the program Nano2021 to the project (Number 228355) "Functional oxides for clean energy technologies: fuel cells, gas separation membranes and electrolysers" (FOXCET) conducted by SINTEF Materials and Chemistry, University of Oslo and The Norwegian Institute of Science and Technology is gratefully acknowledged. We also acknowledge financial support from the NTNU's Publishing Fund. C.B.-L. also acknowledges L.R.-M. for discussions on general thermodynamics and E.B.-D- for fruitful discussions.

Author Contributions: C.B.-L. and T.G. conceived and designed the experiments; C.B.-L. performed most of the experiments; K.H. performed the HT-XRD experiments; C.B.-L. analyzed the data; M.-A.E. contributed in the synthesis of the materials; and C.B.-L. wrote the manuscripts and the rest of the authors gave comments to it.

Conflicts of Interest: The authors declare no conflict of interest. 


\section{Abbreviations}

The following abbreviations are used in this manuscript:

RT Room Temperature

LDP Layered double perovskite

SOFC Solid oxide fuel cells

XRD X-Ray Diffraction data

YSZ Yttria-stabilised zirconia

SEM Scanning electron microscopy

HT-XRD High temperature $x$-ray diffraction

PV-TCHZ Thomson Cox-Hastings pseudo-Voigt

TGA Thermogravimetric analysis

TEC Thermal expansion coefficient

\section{References}

1. Sengodan, S.; Choi, S.; Jun, A.; Shin, T.H.; Ju, Y.W.; Jeong, H.Y.; Shin, J.; Irvine, J.T.S.; Kim, G. Layered oxygen-deficient double perovskite as an efficient and stable anode for direct hydrocarbon solid oxide fuel cells. Nat. Mater. 2015, 14, 205-209. [CrossRef] [PubMed]

2. Broux, T.; Bahout, M.; Hanlon, J.M.; Hernandez, O.; Paofai, S.; Berenov, A.; Skinner, S.J. High temperature structural stability, electrical properties and chemical reactivity of $\mathrm{NdBaCo}_{2-x} \mathrm{Mn}_{\mathrm{x}} \mathrm{O}_{5+\delta}(0 \leqslant \mathrm{x} \leqslant 2)$ for use as cathodes in solid oxide fuel cells. J. Mater. Chem. A 2014, 2, 17015-17023. [CrossRef]

3. Kim, G.; Wang, S.; Jacobson, A.J.; Reimus, L.; Brodersen, P.; Mims, C.A. Rapid oxygen ion diffusion and surface exchange kinetics in $\mathrm{PrBaCO}_{2} \mathrm{O}_{5+x}$ with a perovskite related structure and ordered a cations. J. Mater. Chem. 2007, 17, 2500-2505. [CrossRef]

4. Tarancón, A.; Burriel, M.; Santiso, J.; Skinner, S.J.; Kilner, J.A. Advances in layered oxide cathodes for intermediate temperature solid oxide fuel cells. J. Mater. Chem. 2010, 20, 3799-3813. [CrossRef]

5. Tarancón, A.; Skinner, S.J.; Chater, R.J.; Hernández-Ramírez, F.; Kilner, J.A. Layered perovskites as promising cathodes for intermediate temperature solid oxide fuel cells. J. Mater. Chem. 2007, 17, 3175-3181. [CrossRef]

6. Pelosato, R.; Cordaro, G.; Stucchi, D.; Cristiani, C.; Dotelli, G. Cobalt based layered perovskites as cathode material for intermediate temperature Solid Oxide Fuel Cells: A brief review. J. Power Sources 2015, 298, 46-67. [CrossRef]

7. Kim, J.H.; Manthiram, A. $\mathrm{LnBaCo}_{2} \mathrm{O}_{5+\delta}$ oxides as cathodes for intermediate-temperature solid oxide fuel cells. J. Electrochem. Soc. 2008, 155, B385-B390. [CrossRef]

8. Kim, J.-H.; Manthiram, A. Layered $\mathrm{LnBaCo}_{2} \mathrm{O}_{5+\delta}$ perovskite cathodes for solid oxide fuel cells: An overview and perspective. J. Mater. Chem. A 2015, 3, 24195-24210. [CrossRef]

9. Kim, J.P.; Pyo, D.W.; Magnone, E.; Park, J.H. Preparation and oxygen permeability of $\mathrm{ReBaCo}_{2} \mathrm{O}_{5+\delta}(\mathrm{Re}=\mathrm{Pr}$, $\mathrm{Nd}, \mathrm{Y}$ ) ceramic membranes. Adv. Mater. Res. 2012, 560-561, 959-964. [CrossRef]

10. Zhang, K.; Ge, L.; Ran, R.; Shao, Z.; Liu, S. Synthesis, characterization and evaluation of cation-ordered $\mathrm{LnBaCo}_{2} \mathrm{O}_{5+\delta}$ as materials of oxygen permeation membranes and cathodes of SOFCs. Acta Mater. 2008, 56, 4876-4889. [CrossRef]

11. King, G.; Woodward, P.M. Cation ordering in perovskites. J. Mater. Chem. 2010, 20, 5785-5796. [CrossRef]

12. Troyanchuk, I.O.; Kasper, N.V.; Khalyavin, D.D.; Szymczak, H.; Szymczak, R.; Baran, M. Magnetic and electrical transport properties of orthocobaltites $\mathrm{R}_{0.5} \mathrm{Ba}_{0.5} \mathrm{CoO}_{3}(\mathrm{R}=\mathrm{La}, \mathrm{Pr}, \mathrm{Nd}, \mathrm{Sm}, \mathrm{Eu}, \mathrm{Gd}, \mathrm{Tb}, \mathrm{Dy})$. Phys. Rev. B 1998, 58, 2418-2421. [CrossRef]

13. Maignan, A.; Martin, C.; Pelloquin, D.; Nguyen, N.; Raveau, B. Structural and Magnetic Studies of Ordered Oxygen-Deficient Perovskites $\mathrm{LnBaCO}_{2} \mathrm{O}_{5+\delta}$, Closely Related to the "112" Structure. J. Solid State Chem. 1999, 142, 247-260. [CrossRef]

14. Muñoz-Gil, D.; Ávila-Brande, D.; Urones-Garrote, E.; García-Martín, S. Ordering effects in the crystal structure and electrochemical properties of the $\mathrm{Gd}_{0.5} \mathrm{Ba}_{0.5} \mathrm{Mn}_{0.5} \mathrm{Fe}_{0.5} \mathrm{O}_{3-\delta}$ perovskite. Dalton Trans. 2015, 44, 10867-10874. [CrossRef] [PubMed] 
15. Rautama, E.L.; Caignaert, V.; Boullay, P.; Kundu, A.K.; Pralong, V.; Karppinen, M.; Ritter, C.; Raveau, B. New Member of the "112" Family, $\mathrm{LaBaCo}_{2} \mathrm{O}_{5.5}$ : Synthesis, Structure, and Magnetism. Chem. Mater. 2008, 21, 102-109. [CrossRef]

16. Streule, S.; Podlesnyak, A.; Mesot, J.; Medarde, M.; Conder, K.; Pomjakushina, E.; Mitberg, E.; Kozhevnikov, V. Effect of oxygen ordering on the structural and magnetic properties of the layered perovskites $\operatorname{PrBaCo}_{2} \mathrm{O}_{5+\delta}$. J. Phys. Condens. Matter 2005, 17, 3317-3324. [CrossRef]

17. Frontera, C.; Caneiro, A.; Carrillo, A.E.; Oró-Solé, J.; García-Muñoz, J.L. Tailoring oxygen content on $\mathrm{PrBaCO}_{2} \mathrm{O}_{5+\delta}$ layered cobaltites. Chem. Mater. 2005, 17, 5439-5445. [CrossRef]

18. Burley, J.C.; Mitchell, J.F.; Short, S.; Miller, D.; Tang, Y. Structural and Magnetic Chemistry of $\mathrm{NdBaCO}_{2} \mathrm{O}_{5+\delta}$. J. Solid State Chem. 2003, 170, 339-350. [CrossRef]

19. Akahoshi, D.; Ueda, Y. Oxygen nonstoichiometry, structures, and physical properties of $\mathrm{YBaCo}_{2} \mathrm{O}_{5+x}$ $(0.00 \leqslant x \leqslant 0.52)$. J. Solid State Chem. 2001, 156, 355-363. [CrossRef]

20. Kuang, X.; Allix, M.; Ibberson, R.M.; Claridge, J.B.; Niu, H.; Rosseinsky, M.J. Oxygen Vacancy Ordering Phenomena in the Mixed-Conducting Hexagonal Perovskite $\mathrm{Ba}_{7} \mathrm{Y}_{2} \mathrm{Mn}_{3} \mathrm{Ti}_{2} \mathrm{O}_{20}$. Chem. Mater. 2007, 19, 2884-2893. [CrossRef]

21. Goodenough, J.B.; Ruiz-Diaz, J.E.; Zhen, Y.S. Oxide-ion conduction in $\mathrm{Ba}_{2} \mathrm{In}_{2} \mathrm{O}_{5}$ and $\mathrm{Ba}_{3} \mathrm{In}_{2} \mathrm{MO}_{8}(\mathrm{M}=\mathrm{Ce}, \mathrm{Hf}$, or Zr). Solid State Ion. 1990, 44, 21-31. [CrossRef]

22. Colville, A.A.; Geller, S. The crystal structure of brownmillerite, CaFeAlO 2.5 . Acta Crystallogr. B 1971, 27, 2311-2315. [CrossRef]

23. Setevich, C.; Mogni, L.; Caneiro, A.; Prado, F. Characterization of the $\mathrm{La}_{1-x} \mathrm{Ba}_{\mathrm{x}} \mathrm{CoO}_{3-\delta}(0 \leqslant \mathrm{x} \leqslant 1)$ system as cathode material for it-sofc. J. Electrochem. Soc. 2012, 159, B72-B79. [CrossRef]

24. Atkinson, A.; Ramos, T.M.G.M. Chemically-induced stresses in ceramic oxygen ion-conducting membranes. Solid State Ion. 2000, 129, 259-269. [CrossRef]

25. Bishop, S.R.; Duncan, K.; Wachsman, E.D. Thermo-chemical expansion of SOFC materials. ECS Trans. 2006, 1, 13-21.

26. Sato, K.; Yashiro, K.; Kawada, T.; Yugami, H.; Hashida, T.; Mizusaki, J. Fracture process of nonstoichiometric oxide based solid oxide fuel cell under oxidizing/reducing gradient conditions. J. Power Sources 2010, 195, 5481-5486. [CrossRef]

27. Tietz, F. Thermal expansion of SOFC materials. Ionics 1999, 5, 129-139. [CrossRef]

28. Hendriksen, P.V.; Larsen, P.H.; Mogensen, M.; Poulsen, F.W.; Wiik, K. Prospects and problems of dense oxygen permeable membranes. Catal. Today 2000, 56, 283-295. [CrossRef]

29. Rautama, E.-L.; Boullay, P.; Kundu, A.K.; Caignaert, V.; Pralong, V.; Karppinen, M.; Raveau, B. Cationic Ordering and Microstructural Effects in the Ferromagnetic Perovskite $\mathrm{La}_{0.5} \mathrm{Ba}_{0.5} \mathrm{CoO}_{3}$ : Impact upon Magnetotransport Properties. Chem. Mater. 2008, 20, 2742-2750. [CrossRef]

30. Amin, R.; Karan, K. Characterization of $\mathrm{La}_{0.5} \mathrm{Ba}_{0.5} \mathrm{CoO}_{3-\delta}$ as a SOFC Cathode Material. J. Electrochem. Soc. 2010, 157, B285-B291. [CrossRef]

31. Pang, S.; Jiang, X.; Li, X.; Su, Z.; Xu, H.; Xu, Q.; Chen, C. Characterization of cation-ordered perovskite oxide $\mathrm{LaBaCO}_{2} \mathrm{O}_{5+\delta}$ as cathode of intermediate-temperature solid oxide fuel cells. Int. J. Hydrog. Energy 2012, 37, 6836-6843. [CrossRef]

32. Kim, J.H.; Mogni, L.; Prado, F.; Caneiro, A.; Alonso, J.A.; Manthiram, A. High temperature crystal chemistry and oxygen permeation properties of the mixed ionic-electronic conductors $\mathrm{LnBaCo}_{2} \mathrm{O}_{5+\delta}(\mathrm{Ln}=$ Lanthanide). J. Electrochem. Soc. 2009, 156, B1376-B1382. [CrossRef]

33. Kröger, F.A.; Vink, H.J. Relations between the Concentrations of Imperfections in Crystalline Solids. Solid State Phys. 1956, 3, 307-435.

34. Garces, D.; Setevich, C.F.; Caneiro, A.; Cuello, G.J.; Mogni, L. Effect of cationic order-disorder on the transport properties of $\mathrm{LaBaCo}_{2} \mathrm{O}_{6-\delta}$ and $\mathrm{La}_{0.5} \mathrm{Ba}_{0.5} \mathrm{CoO}_{3-\delta}$ perovskites. J. Appl. Crystallogr. 2014, 47, 325-334. [CrossRef]

35. Rautama, E.-L.; Karppinen, M. R-site varied series of $\mathrm{RBaCo}_{2} \mathrm{O}_{5.5}\left(\mathrm{R}_{2} \mathrm{Ba}_{2} \mathrm{Co}_{4} \mathrm{O}_{11}\right)$ compounds with precisely controlled oxygen content. J. Solid State Chem. 2010, 183, 1102-1107. [CrossRef]

36. Tsvetkov, D.S.; Ivanov, I.L.; Malyshkin, D.A.; Zuev, A.Y. Oxygen content, crystal structure and chemical expansion of $\mathrm{PrBaCO}_{2-x} \mathrm{Fe}_{x} \mathrm{O}_{6-\delta}$ double perovskites. Dalton Trans. 2014, 43, 11862-11866. [CrossRef] [PubMed] 
37. Ishizawa, N.; Asaka, T.; Kudo, T.; Fukuda, K.; Yasuhara, A.; Abe, N.; Arima, T.H. Structural evolution of $\mathrm{GdBaCo}_{2} \mathrm{O}_{5+\sigma}(\delta=7 / 18)$ at elevated temperatures. Chem. Mater. 2014, 26, 6503-6517. [CrossRef]

38. McKinlay, A.; Connor, P.; Irvine, J.T.S.; Zhou, W. Structural chemistry and conductivity of a solid solution of $\mathrm{YBa}_{1-x} \mathrm{Sr}_{\mathrm{x}} \mathrm{Co}_{2} \mathrm{O}_{5+\delta}$. J. Phys. Chem. C 2007, 111, 19120-19125. [CrossRef]

39. Kim, J.H.; Kim, Y.N.; Bi, Z.; Manthiram, A.; Paranthaman, M.P.; Huq, A. Overcoming phase instability of $\mathrm{RBaCo}_{2} \mathrm{O}_{5+\delta}(\mathrm{R}=\mathrm{y}$ and $\mathrm{Ho})$ by $\mathrm{Sr}$ substitution for application as cathodes in solid oxide fuel cells. Solid State Ion. 2013, 253, 81-87. [CrossRef]

40. Kim, J.H.; Prado, F.; Manthiram, A. Characterization of $\mathrm{GdBa}_{1-x} \mathrm{Sr}_{\mathrm{x}} \mathrm{Co}_{2} \mathrm{O}_{5+\delta}(0 \leqslant \mathrm{x} \leqslant 1.0)$ Double Perovskites as Cathodes for Solid Oxide Fuel Cells. J. Electrochem. Soc. 2008, 155, B1023-B1028. [CrossRef]

41. Mogni, L.; Prado, F.; Jiménez, C.; Caneiro, A. Oxygen order-disorder phase transition in layered $\mathrm{GdBaCo}_{2} \mathrm{O}_{5+\delta}$ perovskite: Thermodynamic and transport properties. Solid State Ion. 2013, 240, 19-28. [CrossRef]

42. Adler, S.B. Chemical Expansivity of Electrochemical Ceramics. J. Am. Ceram. Soc. 2001, 84, $2117-2119$. [CrossRef]

43. Oygarden, V.; Lein, H.L.; Grande, T. Structure, thermal expansion and electrical conductivity of $\mathrm{Nb}$-substituted $\mathrm{LaCoO}_{3}$. J. Solid State Chem. 2012, 192, 246-254. [CrossRef]

44. Chen, X.; Grande, T. Anisotropic chemical expansion of $\mathrm{La}_{1-x} \mathrm{Sr}_{x} \mathrm{CoO}_{3-\delta}$. Chem. Mater. 2013, $25,927-934$. [CrossRef]

45. Petrov, A.N.; Cherepanov, V.A.; Zuev, A.Y. Thermodynamics, defect structure, and charge transfer in doped lanthanum cobaltites: An overview. J. Solid State Electrochem. 2006, 10, 517-537. [CrossRef]

46. Rietveld, H.M. A profile refinement method for nuclear and magnetic structures. J. Appl. Crystallogr. 1969, 2, 65-71. [CrossRef]

47. Wærnhus, I.; Vullum, P.E.; Holmestad, R.; Grande, T.; Wiik, K. Electronic properties of polycrystalline $\mathrm{LaFeO}_{3}$. Part I: Experimental results and the qualitative role of Schottky defects. Solid State Ion. 2005, 176, 2783-2790. [CrossRef]

(C) 2016 by the authors; licensee MDPI, Basel, Switzerland. This article is an open access article distributed under the terms and conditions of the Creative Commons by Attribution (CC-BY) license (http://creativecommons.org/licenses/by/4.0/). 